OPEN ACCESS

Edited by:

Upendra Kumar,

National Rice Research Institute

(ICAR), India

Reviewed by:

Mahendra Vikram Singh Rajawat, National Bureau of Agriculturally

Important Microorganisms (ICAR), India Himani Priya,

Indian Council of Agricultural Research (ICAR), India

*Correspondence:

Yalavarthi Nagaraju nagarajulvrth62@gmail.com

Specialty section:

This article was submitted to

Plant-Soil Interactions,

a section of the journal

Frontiers in Agronomy

Received: 15 March 2021 Accepted: 07 October 2021 Published: 18 November 2021

Citation:

Nagaraju Y, Mahadevaswamy, Naik NM, Gowdar SB, Narayanarao K and Satyanarayanarao K (2021) ACC

Deaminase-Positive Halophilic Bacterial Isolates With Multiple Plant Growth-Promoting Traits Improve the Growth and Yield of Chickpea (Cicer arietinum L.) Under Salinity Stress. Front. Agron. 3:681007.

doi: 10.3389/fagro.2021.681007

\section{ACC Deaminase-Positive Halophilic Bacterial Isolates With Multiple Plant Growth-Promoting Traits Improve the Growth and Yield of Chickpea (Cicer arietinum L.) Under Salinity Stress}

\author{
Yalavarthi Nagaraju ${ }^{1 *}$ Mahadevaswamy ${ }^{2}$, Nagaraj M. Naik ${ }^{3}$, S. B. Gowdar ${ }^{4}$, \\ K. Narayanarao ${ }^{5}$ and K. Satyanarayanarao ${ }^{6}$
}

${ }^{1}$ Department of Agricultural Microbiology, University of Agricultural Sciences (UAS), Raichur, India, ${ }^{2}$ Department of Agricultural Microbiology, College of Agriculture, University of Agricultural Sciences (UAS), Raichur, India, ${ }^{3}$ Pesticide Residue and Food Quality Analysis Lab (PRFQAL), University of Agricultural Sciences (UAS), Raichur, India, ${ }^{4}$ Department of Plant Pathology, University of Agricultural Sciences (UAS), Raichur, India, ${ }^{5}$ Department of Soil Science and Agricultural Chemistry, College of Agriculture, University of Agricultural Sciences (UAS), Raichur, India, ${ }^{6}$ PGS, University of Agricultural Sciences (UAS), Raichur, India

In this study, a total of 50 halophilic bacterial isolates were screened for 1-aminocyclopropane-1-carboxylate (ACC) deaminase activity, of these six with the highest ACC deaminase activity were selected for an increase in chickpea yield under salinity. The ACC deaminase activity among the isolates was ranged between 0.12 and $3.56 \mathrm{mM} \alpha-\mathrm{KB} \mathrm{mg}^{-1} \mathrm{~min}^{-1}$. These six isolates and one reference strain from the Agricultural College, Raichur, were used in the microcosm experiment during the rabi season of 2018. After 60 days of sowing, decreased rhizosphere $\mathrm{pH}$ and electrical conductivity (EC) from 8.4 to 7.6 and 4.3 to $3.4 \mathrm{dS} \mathrm{m}^{-1}$, respectively, were reported in chickpea. Among the treatments, Bacillus safensis (B. safensis)-inoculated plants showed a higher number of flowers (71 flowers/plant), pods (49.3 pods/plant), branches (33.3 branches/plant), and enhanced fresh weight (17.2 g/plant) and dry weight (8.1 $\mathrm{g} /$ plant). They were corroborated by improved nitrogen and phosphorus absorption of 71.5 and $43.5 \%$, respectively, in B. safensis-treated plants. Based on the microcosm experimental findings, three cultures improving biometric and yield attributes were chosen for the field investigation. The field study was carried out at the Agricultural Research Station, Ganagavathi, during Kharif 2019. The chickpea plants treated with the consortium [B. safensis, Pseudomonas stutzeri, and Staphylococcus xylosus] increased the superoxide dismutase and catalase activity of plants by 258 and 196\%, respectively. In addition, an increase in ascorbate peroxidase activity $(0.41 \mu \mathrm{mol}$ of ascorbate oxidized $\mathrm{s}^{-1} \mathrm{~g}^{-1}$ fresh weight) in the leaves and proline content was also recorded. The consortium (B. safensis, P. stutzeri, and S. xylosus) significantly increased nutrient uptake ( $\mathrm{N}$ and $\mathrm{P}$ ), the number of flowers, number of pods, and yield by $63.26,39.03,110$, 59.96 , and $17.56 \%$, respectively, in chickpeas. Finally, inoculation with a mixture of three isolates is an effective method for increasing chickpea production under osmotic stress.

Keywords: salinity, chickpea, microhabitats, Bacillus safensis, pH, ACC deaminase 


\section{INTRODUCTION}

Salinity affects more than $6 \%$ of the land area globally exacerbated by the high temperatures and low rainfall (Etesami and Maheshwari, 2018). In India, statewide estimates showed an extensive area distribution across the Gangetic Plain of Uttar Pradesh, arid and semiarid regions of Gujarat, and peninsular plains of Maharashtra. There is also $3.1 \mathrm{M}$ ha of land in the coastal zone encompassing seven states of India (Mandal et al., 2009). Salt-affected regions are one of the crucial degraded regions wherein soil productivity was decreased because of salinization [electrical conductivity $(\mathrm{EC})>4 \mathrm{dS} \mathrm{m}^{-1}$ ], sodicity [exchangeable sodium percentage $(\mathrm{ESP})>15 \%$ ], or both. Soil salinity poses a massive challenge for the cultivation of crops and substantially impacts growth and yields. Salt influences plant growth mainly through the poisonousness brought about by the unnecessary take-up of salts, particularly sodium chloride $(\mathrm{NaCl})(\mathrm{FAO}, 2005)$. Soil salinity minimizes the process of plant photosynthesis because of the mind-boggling complex negative impacts of osmotic, ionic, and nutritional interactions (Shirokova et al., 2000). Most flora is vulnerable to salinity pressure (glycophytes); yet, a few plants endure and develop within sight of salts (halophytes). Aggregates of environmental adaptations and intrinsic hereditary characteristics modulate salinity resilience systems in glycophytes and halophytes (Munns, 2002). Glycophytes will, in general, exclude the salts from the roots, postponing the salinity stress (Zhu, 2007). Conversely, halophytes amass salts, carrying them through the xylem stream, and precipitating them into the leaves. A few halophyte groups have advanced with specialized cells called salt glands in shoots to discharge salt to its surface and then expelled by water or wind (Flowers and Colmer, 2015).

Legumes are essential due to their one of a kind dinitrogen fixation potential, high protein content, mineral nutrients, and occupy $12-15 \%$ of arable lands in the world (Flexas et al., 2004). In any case, cultivated legumes are moderate to profoundly sensitive to salinity and just a couple of agronomical legumes can grow in the salt-affected soils (Ashraf and McNeilly, 2004; Singh et al., 2018). For instance, two annual pasture legumes, messina (Melilotus siculus) and burr medic (Medicago polymorpha), can grow in soils with an EC up to $36 \mathrm{dS}$ $\mathrm{m}^{-1}$ (Rogers et al., 2005). Chickpea is commonly grown for animal feed and human food in semiarid regions globally and yield losses are $8-10 \%$ per annum globally due to salinity (Flowers et al., 2010). Chickpea is grown in many environments; however, being highly susceptible to salinity results in reduced productivity per hectare (Atieno et al., 2017). Negative impacts of salinity can be observed during the reproductive stage of crop (Turner et al., 2013). Reduction in the external osmotic potential meddles with water take-up of plants, promoting diminished plant biomass (Boursiac et al., 2005). Photosynthesis hampered by the prolonged exposure to $\mathrm{Na}^{+}$and $\mathrm{Cl}^{-}$ions and plants keep up the net $\mathrm{Na}^{+}$take-up by excluding through transpiration stream in young leaves. Several plants can endure the salinity stress by accumulating compatible solutes and osmotic adjustments (Munns and Tester, 2008). Plant breeding strategies are constrained by the lack of information on critical traits responsible for inferior performance under raised salinity. The presence of a tremendous number of germplasms with the slightest genetic variation hinders success and pulls a lot of investment and labor. Microbial-based technologies are financially savvy, eco-friendly, practical, and sustainable (Etesami and Glick, 2020).

Plant growth-promoting rhizobacteria (PGPR) from saline soils improves glycophytic growth of plants that result in high salinity levels (Barassi et al., 2006). These bacteria endure a wide range of salinity stresses and empower plants to withstand by improving hydraulic conductivity, osmolyte accumulation, toxic ions $\left(\mathrm{Na}^{+}\right)$removal, and keeping up photosynthetic activity (Dodd and Alfocea, 2012). Further, amassing compatible solutes in the cytoplasm and/or inorganic ions, such as sodium, potassium, and chloride, stabilizes the biological structures (Mandal et al., 2009). Rise of ethylene levels because of the excess accumulation of $\mathrm{Na}^{+}$and $\mathrm{Cl}^{-}$ions in plants causes leaf senescence and necrosis (Campbell et al., 2015). Ethylene altogether represses shoot and root prolongation and minimizes plant height and growth in general development (Klassen and Bugbee, 2002). PGPR from stressed environments generally exhibits 1-aminocyclopropane-1-carboxylate (ACC) deaminase activity, which decreases the degree of ACC and endogenous ethylene (Ansari et al., 2019). Halophilic bacteria with ACC deaminase activity mitigate the pernicious effects of salt stress on plant growth. The plants immunized with ACC deaminasepositive PGPR are more tolerant to salt stress (Nishimura et al., 2007; Tiwari et al., 2016). Microbial reduction of rhizosphere $\mathrm{pH}$ was well studied, although utilizing facultative anaerobe never endeavored. The more significant part of the studies focused on the solubilization of minerals by the organic and inorganic acids. This study made endeavors to assess the plant growth-promoting halophilic facultative anaerobes in soil acidification and salt stress alleviation in chickpea plants.

\section{MATERIALS AND METHODS}

\section{In vitro Screening for ACC Deaminase Production}

A total of 50 halophilic bacteria were isolated from the saline soils of Raichur and Ganagavathi. All the bacterial isolates (50) were grown separately in $5 \mathrm{ml}$ of Tryptic Soy Broth (TSB) and incubated for $24 \mathrm{~h}$ at $28^{\circ} \mathrm{C}$ at $120 \mathrm{rpm}$ and then cells were harvested as cell pellets centrifugation at 3,000 rpm for $5 \mathrm{~min}$. Cell pellets were subsequently washed twice with sterile $0.1 \mathrm{M}$ Tris$\mathrm{HCl}(\mathrm{pH} \mathrm{7.5)}$ and resuspended in $1 \mathrm{ml}$ of $0.1 \mathrm{M}$ Tris- $\mathrm{HCl}(\mathrm{pH}$ 7.5) and eventually spot inoculated on modified Dworkin and Foster (DF) minimal medium (Dworkin and Foster, 1958). The DF minimal medium without ACC served as negative control and positive control with ammonium sulfate $\left[\left(\mathrm{NH}_{4}\right)_{2} \mathrm{SO}_{4}\right](0.2$ $\% \mathrm{w} / \mathrm{v})$. The plates were incubated for $72 \mathrm{~h}$ at $28^{\circ} \mathrm{C}$, the growth of isolates on ACC supplemented plates was compared with the negative and positive controls, and the samples were chosen based on bacterial content. The amount of $\alpha$-ketoglutarate produced was determined by using a standard curve and the absorbance was recorded at $540 \mathrm{~nm}$ (Ali et al., 2014). 
Of these, seven isolates with the highest ACC deaminase activity and plant growth-promoting attributes such as solubilization of $\mathrm{Zn}$ and $\mathrm{P}$, the release of $\mathrm{K}$, and indole-3acetic acid (IAA) production at $10 \% \mathrm{NaCl}$ were selected based on the previous studies of Nagaraju et al. (2020). The treatments were imposed for microcosm study by inoculating the individual cultures of Bacillus albus (MN098871.1, HB-4), Bacillus safensis (B. safensis) (MN121550.1, HB-5), Pseudomonas stutzeri (P. stutzeri) strain 1 (MN098847.1, HB-13), Lysinibacillus sphaericus (MZ413352, HB-15), Staphylococcus xylosus (S. xylosus) (MZ413353, HB-18), P. stutzeri strain 2 (MZ413354, HB-41), and Pseudomonas spp. (GP-21) (52). The treatments were compared with the uninoculated controls treated with $100 \%$ recommended dose of fertilizer (RDF) and 75\% RDF under saline conditions.

\section{Soil Acidification Test}

A method was developed to identify the soil acidification by halophilic bacteria; for this test, sterilized saline soil $(\mathrm{pH} \geq 8$ and $\mathrm{EC}=4.2 \pm 0.2 \mathrm{dS} \mathrm{m} \mathrm{m}^{-1}$ ) was used (collected from the Agricultural Research Station, Gangavathi Farm). A composite soil sample $\left(\mathrm{pH} \geq 8\right.$ and EC $4.2 \pm 0.2 \mathrm{dS} \mathrm{m}^{-1}$ ) was collected and a small fraction weighing approximately $30 \mathrm{~g}$ was shared into $250 \mathrm{ml}$ of sterile Erlenmeyer flasks under the aseptic conditions. Subsequently, $60 \mathrm{ml}$ of double-distilled sterile water, $1-2 \%$ glucose, and $0.04 \mathrm{~g}$ of bromothymol blue were administered. Finally, each flask was inoculated with a single acid-producing PGPR-halophilic bacterial isolate; a total of eight treatments were imposed with three replications and control remained untreated. Flasks were sealed with a nonabsorbent cotton plug and incubated at $37 \pm 2^{\circ} \mathrm{C}$ at $120 \mathrm{rpm}$ in a rotary shaker. Observations such as $\mathrm{pH}$ and $\mathrm{EC}$ were recorded at the 5, 10, and 15 days after inoculation (DAI) and subsequent color changes were reported from blue to green (alkaline) or yellow (acidic).

\section{Microcosm Experiment}

From the Gangavathi area, the experimental soil was collected and used for the microcosm study from November 2017 to March 2018. Pots were filled with about $5 \mathrm{~kg}$ of soil (clay loamy) with an initial $\mathrm{pH}$ and $\mathrm{EC}$ around 8.4 and $4.0 \mathrm{dS} \mathrm{m}^{-1}$, respectively. The experiment was conducted at the Glasshouse, Agricultural college, University for Agricultural Sciences (UAS), Raichur. The experiment was laid out in a completely randomized design (CRD) with eight treatments including one control consisting of 24 total experimental units (pots). High-yielding chickpea (TAU-1) seeds were collected from the Seed Unit, College of Agriculture, Raichur, India and sterilized for $30 \mathrm{~s}$ using 1\% sodium hypochlorite preceded by sterile distilled water rinsing and cleaning (Han and Lee, 2005). Treatments were imposed on each by inoculating one efficient strain. Seven halophilic bacterial isolates were grown separately in nutrient broth $(250 \mathrm{ml}$ supplemented with $3 \% \mathrm{NaCl}$ ) at $37^{\circ} \mathrm{C}$ for 4 days at $120 \mathrm{rpm}$. Later, individual cultures were mixed with lignite powder @ 1:3 and allowed to be cured overnight. Finally, chickpea seeds were treated with inoculum, leaving the control untreated. Seeds were planted at a rate of eight seeds per pot and a $4-5 \mathrm{~cm}$ depth. Normal $\mathrm{pH}$ and EC testing were carried out at intervals of 15 days. After 5 days of seedling emergence, chickpea seedlings were irrigated daily with an equal amount of $4 \mathrm{dS} / \mathrm{m}(40 \mathrm{mM}$ $\mathrm{NaCl}$ to maintain salinity stress) solution. As per the standard protocols, soil samples were tested for physiochemical properties such as $\mathrm{pH}, \mathrm{EC}$, phosphorus, organic carbon, nitrogen, and potassium at regular intervals (Subbiah and Asija, 1956; Piper, 1966; Jackson, 1973). The experimental data obtained from this experiment were subjected to statistical analysis by using a completely randomized block design (CRD) and grouping was carried out by using the Tukey's method.

\section{Field Experiment}

The chickpea field experiment was performed from November 2018 to February 2019 at the Agricultural Research Station, Gangavathi, Koppal, India $\left(15^{\circ} 27^{\prime} \mathrm{N}, 76^{\circ} 31^{\prime} \mathrm{E}\right)$. The soil of experimental site is a deep, well-drained clay loamy with an initial $\mathrm{pH}$ and $\mathrm{EC}$ of $8.2 \pm 0.2$ and $4.2 \pm 0.2 \mathrm{dS} \mathrm{m}^{-1}$, respectively. No fertilizer amendments were followed before planting. The same TAU-1 variety grown in the microcosm study was planted in the field study. Seeds were sown at a rate of 43 seeds $\mathrm{m}^{-2}$ and a depth of $3-5 \mathrm{~cm}$. The plots were arranged in a randomized complete block design with four replications. The plot size was $5 \mathrm{~m}^{-2} \times 3 \mathrm{~m}^{-2}$ with a row spacing of $30 \mathrm{~cm}$ seeds were treated with the three isolates which increased plant height, root length, nodulation, and the yield of chickpea in microcosm studies such as B. safensis (HB-5), P. stutzeri strain 1 (HB13), and S. xylosus (HB-18). For both the pot culture and field experiments, biometric observations such as plant height, root length, number of branches plant ${ }^{-1}$, fresh weight of shoot and root, dry weight of shoot and root after drying at $65^{\circ} \mathrm{C}$ for 4 days, number of flowers, number of pods, nitrogen (nitrogen uptake was calculated by multiplying the concentration of $\mathrm{N}$ by the amount of dry matter produced), phosphorus, and number of root nodules were made at regular intervals $(30,60$ days, and at harvest) (Piper, 1966). Grain yield was analyzed at 14\% moisture content before statistical analysis. Furthermore, rhizosphere soil samples were collected intermittently at 30, 60 days, and at harvest stages and soil $\mathrm{pH}$ was analyzed by using the standard protocols (Piper, 1966). The experimental data obtained from a field experiment (in vivo) was analyzed by using a randomized block design (RBD). All the values are grouped based on the Tukey's pairwise and 95\% CI method.

\section{Antioxidant Enzyme Activities}

A total of $1 \mathrm{~g}$ of each leaf and root samples were frozen and then grounded in $4 \mathrm{ml}$ of $50 \mathrm{mM}$ phosphate buffer solution $(\mathrm{pH} 7.0)$ and $1 \%$ polyvinylpyrrolidone (PVP) (w/v). At 15,000 $\times \mathrm{g}$ for $30 \mathrm{~min}$ at $4^{\circ} \mathrm{C}$, the homogenate was centrifuged and the supernatant was collected for enzymatic assays. Superoxide dismutase (SOD) activity in plates has been determined according to Giannopolities and Ries (1977) method. One unit of enzyme activity was determined by monitoring the absorbance at $560 \mathrm{~nm}$ as the amount of enzyme to achieve a $50 \%$ Nitroblue tetrazolium (NBT) reduction rate. Catalase activity (CAT) was calculated by monitoring a decrease in absorbance at $240 \mathrm{~nm}$ for $1 \mathrm{~min}$ (extinction coefficient of $0.036 \mathrm{mM}^{-1} \mathrm{~cm}$ ${ }^{-1}$ ) (Change and Maehly, 1955). The enzyme required to break down $1 \mu$ mol hydrogen peroxide $\left(\mathrm{H}_{2} \mathrm{O}_{2}\right)$ per min at $25^{\circ} \mathrm{C}$ was specified as one unit of activity. For ascorbate peroxidase 
TABLE 1 | Influence of facultative anaerobic halophilic bacteria on pH and electrical conductivity (EC) of saline soil.

\begin{tabular}{|c|c|c|c|c|c|c|c|c|c|}
\hline \multirow[t]{2}{*}{ Treatments } & \multicolumn{4}{|c|}{$\mathrm{pH}$} & \multirow[t]{2}{*}{ Final Color of Soil Solution } & \multicolumn{4}{|c|}{ E.C. } \\
\hline & Initial & 5 DAl & $10 \mathrm{DAl}$ & $15 \mathrm{DAl}$ & & Initial & 5 DAI & $10 \mathrm{DAl}$ & $15 \mathrm{DAl}$ \\
\hline $\mathrm{T}_{1}: 30 \mathrm{gm}$ of soil (Control) & 8.42 & 8.41 & 8.42 & 8.40 & Green & 3.72 & 3.69 & 3.84 & 3.77 \\
\hline $\begin{array}{l}\mathrm{T}_{2}: 30 \mathrm{gm} \text { of soil }+1 \% \text { glucose } \\
\text { (uninoculated control } 1 \text { ) }\end{array}$ & 8.46 & 8.46 & 8.41 & 8.39 & Green & 3.89 & 3.92 & 3.86 & 3.88 \\
\hline $\begin{array}{l}\mathrm{T}_{3}: 30 \mathrm{gm} \text { of soil }+2 \% \text { glucose } \\
\text { (uninoculated control } 2 \text { ) }\end{array}$ & 8.54 & 8.55 & 8.46 & 8.44 & Green & 4.08 & 4.10 & 4.02 & 4.06 \\
\hline $\begin{array}{l}\mathrm{T}_{4}: 30 \mathrm{gm} \text { of soil }+ \text { Bacillus safensis } \\
+1 \% \text { glucose }\end{array}$ & 8.36 & 7.88 & 7.86 & 7.89 & Blue to green & 3.76 & 3.81 & 3.79 & 3.70 \\
\hline $\begin{array}{l}\mathrm{T}_{5}: 30 \mathrm{gm} \text { of soil }+ \text { Bacillus safensis } \\
+2 \% \text { glucose }\end{array}$ & 8.61 & 7.55 & 7.91 & 7.95 & Light blue & 3.84 & 3.22 & 3.15 & 3.35 \\
\hline $\begin{array}{l}\mathrm{T}_{6}: 30 \mathrm{gm} \text { of soil }+ \text { Pseudomonas } \\
\text { stutzeri }+1 \% \text { glucose }\end{array}$ & 8.25 & 7.48 & 7.47 & 7.88 & Light blue & 4.23 & 3.89 & 3.92 & 4.04 \\
\hline $\begin{array}{l}\mathrm{T}_{7}: 30 \mathrm{gm} \text { of soil }+ \text { Pseudomonas } \\
\text { stutzeri }+2 \% \text { glucose }\end{array}$ & 8.59 & 8.02 & 7.96 & 7.89 & Bluish green & 4.19 & 3.65 & 3.61 & 3.88 \\
\hline $\begin{array}{l}\mathrm{T}_{8}: 30 \mathrm{gm} \text { of soil }+ \text { Staphylococcus } \\
\text { xylosus }+1 \% \text { glucose }\end{array}$ & 8.39 & 8.11 & 8.07 & 7.91 & Bluish green & 3.95 & 3.77 & 3.64 & 3.71 \\
\hline $\begin{array}{l}\mathrm{T}_{9}: 30 \mathrm{gm} \text { of soil }+ \text { Staphylococcus } \\
\text { xylosus }+2 \% \text { glucose }\end{array}$ & 8.71 & 8.19 & 8.05 & 8.23 & Green & 4.14 & 3.53 & 3.69 & 3.88 \\
\hline SEm & 0.065 & 0.138 & 0.109 & 0.084 & & 0.065 & 0.085 & 0.084 & 0.073 \\
\hline CV & 2.315 & 5.139 & 4.029 & 3.108 & & 4.935 & 6.867 & 6.766 & 5.777 \\
\hline
\end{tabular}

activity, plant tissue was homogenized in $100 \mathrm{mM} \mathrm{NaCl}, 5 \mathrm{mM}$ Ethylenediamine tetraacetic acid (EDTA), $5 \mathrm{mM}$ Dithiotreitol (DTT), 2\% (w/v) PVP, and $5 \mathrm{mM}$ ascorbate mixed in $1 \mathrm{ml}$ of $50 \mathrm{mM}$ phosphate buffer ( $\mathrm{pH} 7.8$ ). Further, the homogenized material was centrifuged at $15,000 \times \mathrm{g}$ for $15 \mathrm{~min}$ at $4^{\circ} \mathrm{C}$ (absorbance coefficient $2.8 \mathrm{mM}^{-1} \mathrm{~cm}^{-1}$ ). At $290 \mathrm{~nm}$ absorbance, the reaction rate was measured (Aono et al., 1995). The sum required to decompose $1 \mu \mathrm{mol}$ of ascorbate per min at $25^{\circ} \mathrm{C}$ was described as one enzyme unit. Ascorbic acid was measured by using the procedure outlined by Mukherjee and Choudhuri (1983); in brief, tissues were extracted with 6\% trichloroacetic acid $(10 \mathrm{ml})$, which was mixed with $2 \%$ dinitrophenylhydrazine ( $2 \mathrm{ml}$ ) and one drop of $10 \%$ thiourea in $70 \%$ ethanol. The mixture was boiled for $5 \mathrm{~min}$ in a water bath after which the mixture was allowed to cool at room temperature. At $0^{\circ} \mathrm{C}$, $5 \mathrm{ml}$ of $80 \%(\mathrm{v} / \mathrm{v})$ sulfuric acid $\left(\mathrm{H}_{2} \mathrm{SO}_{4}\right)$ was added to the mixture and absorbance at $530 \mathrm{~nm}$ was reported. The ascorbic acid concentration was determined from a standard curve plotted with the known concentration of ascorbic acid. This experimental data was analyzed by using a CRD.

\section{Estimation of Proline Content}

From microcosm and field-grown chickpea plants, approximately $0.5 \mathrm{~g}$ of fully opened leaf samples were obtained. The samples were homogenized in $10 \mathrm{ml}$ of $3 \%$ aqueous sulfosalicylic acid and the homogenate was extracted through the filter paper. A total of $2 \mathrm{ml}$ of filtrate was reacted with $2 \mathrm{ml}$ of acid ninhydrin and $2 \mathrm{ml}$ of glacial acetic acid for $1 \mathrm{~h}$ at $100^{\circ} \mathrm{C}$ and the reaction was terminated by using an ice bath. The chromophore was extracted by using $4 \mathrm{ml}$ of toluene and its absorbance was measured at $520 \mathrm{~nm}$ by using a spectrophotometer (toluene used as a blank). The proline concentration was estimated from a standard curve and measured on a fresh weight basis by using the formulae (Bates et al., 1973):

$\mu$ moles proline/g of fresh weight material

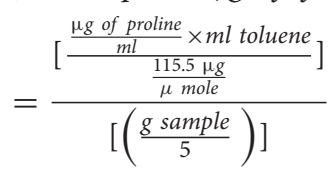

\section{RESULTS}

\section{Soil Acidification by Halophilic Bacteria}

The soil $\mathrm{pH}$ and EC changes were measured with a 1-week interval and the results were promising. Halophilic bacterial inoculation substantially decreased saline soil $\mathrm{pH}$ and EC. The decrease in soil $\mathrm{pH}$ and EC was significant with the treatment of B. safensis (supplemented with $2 \%$ glucose), reduced $\mathrm{pH}$ maximum of $12.31 \%$, and EC up to $17.96 \%$ after 5 days of inoculation. The $\mathrm{pH}$ decrease was peak after 5 days of inoculation and, subsequently, there was a slight increase in $\mathrm{pH}$. In P. stutzeriinoculated treatments, an increase in $\mathrm{pH}$ and $\mathrm{EC}$ was recorded after 15 days (Table $\mathbf{1}$ ).

\section{Qualitative and Quantitative Assay for ACC Deaminase}

A total of 50 halophilic bacterial isolates were isolated on enrichment media from saline soils of Gangavathi, of which 39 isolates were able to grow on DF minimal salt medium supplemented with $3 \mathrm{mM}$ ACC as a source of nitrogen, based on which it was postulated that these isolates were positive for the activity of ACC deaminase. The amount of $\alpha$-ketoglutarate produced by the isolates ranged from 0.12 to $3.56 \mathrm{mM} \alpha \mathrm{KB} \mathrm{mg}^{-1}$ 


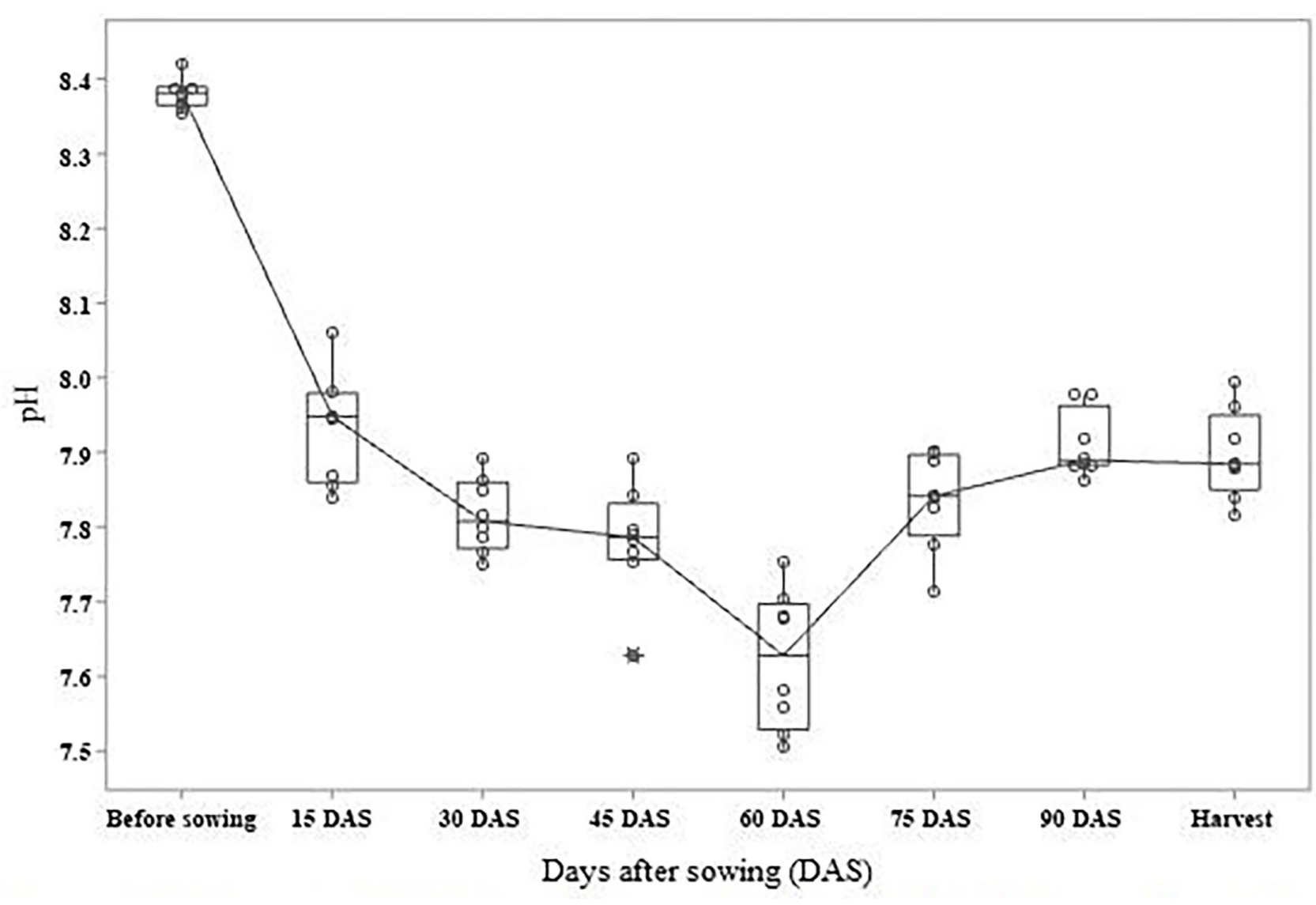

FIGURE 1 | Influence of plant growth promoting halophilic bacteria (PGPHB) on chickpea rhizosphere pH: the reduction in pH of the chickpea rhizosphere commenced after 15 days after planting and reached a maximum after 60 days. The inoculation of PGPHB resulted in an overall decrease in soil pH in all treatments. The treatments having means greater or less than the average mean are denoted by an asterisk $\left(^{*}\right)$.

$\min ^{-1}$. The maximum ACC deaminase production was observed in $B$. safensis with $3.56 \mathrm{mM} \alpha \mathrm{KB} \mathrm{mg}^{-1} \mathrm{~min}^{-1}$.

\section{Effect of Plant Growth-Promoting Halophilic Bacteria (PGPHB) on Chickpea Under Microcosm Conditions}

This experiment was performed at the Glasshouse, Agricultural college, UAS, Raichur during the rabi season of 2017-2018. Uninoculated pots with $40 \mathrm{mM} \mathrm{NaCl}$ (v/v) served as control. The $\mathrm{pH}$ of rhizosphere and $\mathrm{EC}$ were continuously recorded at an interval of 15 days over the entire crop duration. A significant decrease in $\mathrm{pH}$ was recorded after 60 days of sowing, an active crop growth stage (Figure 1), whereas reduction in EC was observed from 30 to 60 days (Figure 2). The maximum intake of nitrogen $(\mathrm{N})$ was reported when $B$. safensis $\left(89.29 \mathrm{~kg} \mathrm{ha}^{-1}\right)$ was inoculated, followed by P. stutzeri $\left(85.29 \mathrm{~kg} \mathrm{ha}^{-1}\right)$ and S. xylosus $\left(85.03 \mathrm{~kg} \mathrm{ha}^{-1}\right)$, and the lowest was observed in control $(52.04 \mathrm{~kg}$ $\left.\mathrm{ha}^{-1}\right)$. Maximum phosphorus uptake was achieved by treatment with B. safensis $\left(20.05 \mathrm{~kg} \mathrm{ha}^{-1}\right)$, followed by P. stutzeri $(18.29 \mathrm{~kg}$ $\left.\mathrm{ha}^{-1}\right), \quad$ S. xylosus $\left(17.52 \mathrm{~kg} \mathrm{ha}{ }^{-1}\right)$, Lysinibacillus sphaericus
(15.92 $\left.\mathrm{kg} \mathrm{ha}^{-1}\right)$, and the lowest was observed in T2 (13.63 $\left.\mathrm{kg} \mathrm{ha}^{-1}\right)$.

In the microcosm experiment, seed bacterization with ACC deaminase-positive PGPHB isolates significantly influenced the growth and yield of chickpea. With the inoculation of $B$. safensis (39.4 and $26.2 \mathrm{~cm}$ ) and $S$. xylosus (39.2 and $23.27 \mathrm{~cm}$ ), maximum plant height and root length were recorded (Table 2). Branch numbers (including primary and secondary) were higher than uninoculated control in the inoculated treatments; B. safensis (33.3 branches/plant) had the most significant number of branches followed by Pseudomonas spp. (30 branches/plant) (Table 2). More fresh weight (including pods) was reported in B. safensis (17.1 g/plant) followed by treated plants with S. xylosus (16.7 g/plant). After inoculation, the highest development of dry matter was obtained by B. safensis ( $8.1 \mathrm{~g} / \mathrm{plant})$ followed by S. xylosus (7.4 g/plant). B. safensis- and S. xylosus-inoculated plants displayed a more significant number of flowers, 71 and 64.3 per plant, respectively. In contrast to the number of flowers, the number of pods per plant was considerably low. The treatment of B. safensis (49.3), followed by S. xylosus (45.6), revealed many pods in uninoculated control; a lower number of pods was reported (33.3). Salinity impeded the nodulation 


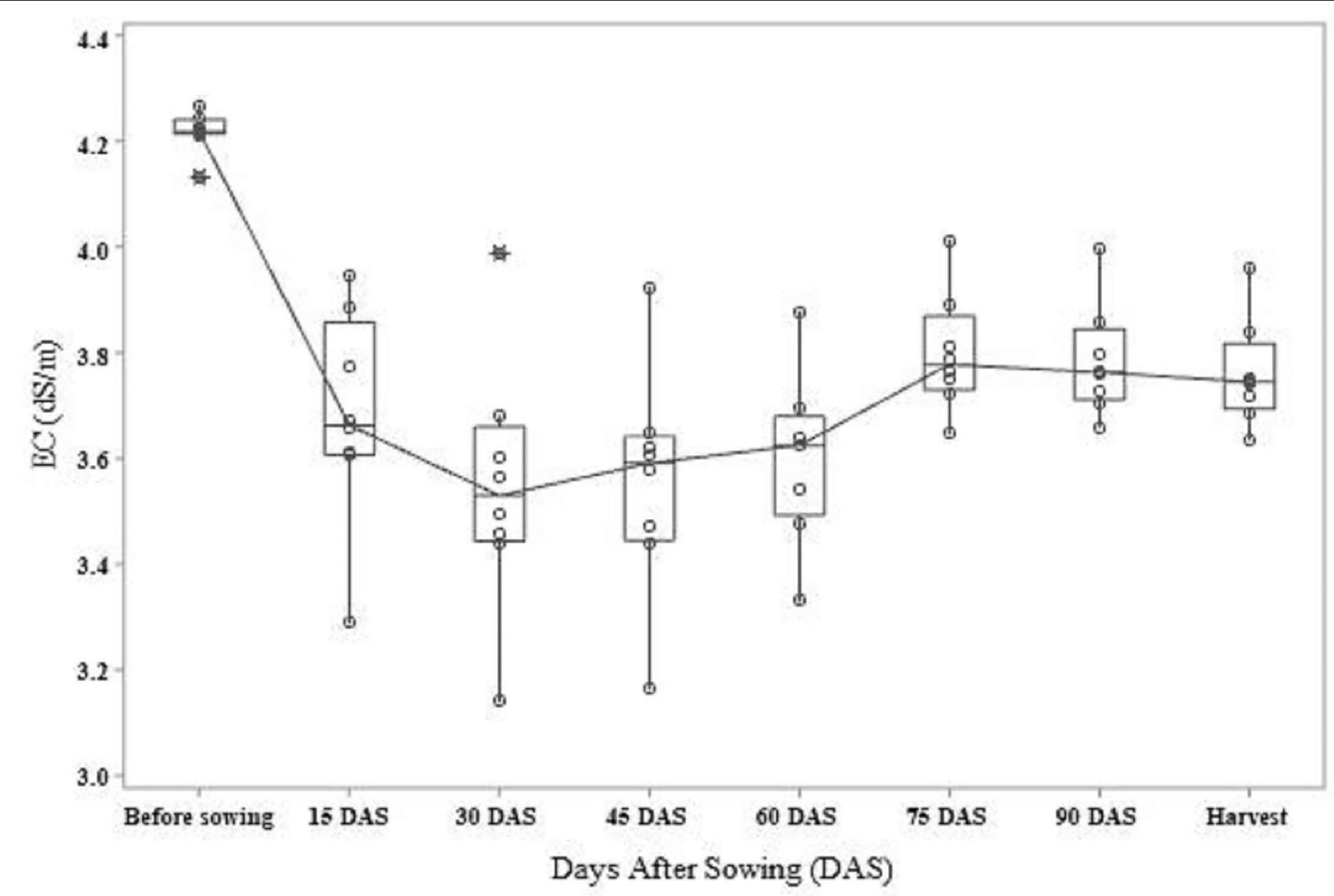

FIGURE 2 | Influence of plant growth promoting halophilic bacteria (PGPHB) on chickpea rhizosphere EC: up to 30 days after planting, there was a continuous reduction in EC, which then stabilised after 60 days. All of the treatments showed a small decrease at harvest. The treatments having means greater or less than the average mean are denoted by an asterisk (*).

entirely in all the treatments. With the treatment of $B$. safensis (13 q/ha), P. stutzeri (11.67 q/ha), and S. xylosus (11.67 q/ha), significant increases in grain yield were reported under salinity stress and the lowest yield was observed in the control treatment (8 q/ha).

\section{Influence of PGPHB on Chickpea Under Field Conditions}

Based on the microcosm experimental results, the three best isolates, viz., B. safensis (HB-5), P. stutzeri strain 1 (HB-13), and S. xylosus (HB-18) were selected for the field study. This investigation was carried out during the rabi season of 20182019 at the Agricultural Research Station, Gangavathi, India. At the beginning of the experiment, $\mathrm{pH}$ and EC were recorded as $\sim 8.38$ and $\sim 4.2 \mathrm{dS} \mathrm{m}^{-1}$, respectively. Significant reduction of $\mathrm{pH}$ and EC was observed after 15 days with the treatment of S. xylosus and B. safensis up to 0.53 and $0.96 \mathrm{dS} \mathrm{m}^{-1}$, respectively. Nitrogen $(\mathrm{N})$ uptake has a positive correlation with the growth and yield of the crop. Consortium of B. safensis + P. stutzeri + S. xylosus showed maximum $\mathrm{N}$ uptake of $71.84 \mathrm{~kg} \mathrm{ha}^{-1}$ followed by B. safensis + P. stutzeri $\left(70.89 \mathrm{~kg} \mathrm{ha}^{-1}\right)$. Similarly, phosphorus uptake was maximum in the B. safensis + P. stutzeri
+ S. xylosus $\left(20.02 \mathrm{~kg} \mathrm{ha}^{-1}\right)$ and the data are shown in Table 3. The shoot length was significantly improved by B. safensis $+P$. stutzeri + S. xylosus inoculation at 30, 60, and 90 days; shoot length was recorded as $10.95,34$, and $48.6 \mathrm{~cm}$, respectively, and the lowest was recorded in the stress-induced control treatment. However, no significant difference was found among the individual inoculated plants. The consortium treatment (B. safensis + P. stutzeri + S. xylosus) improved the root length at 30, 60 days, and harvest; individual inoculation (B. safensis) showed significant enhancement in root length at 60 days. The number of branches was recorded maximum with the treatment of B. safensis + P. stutzeri + S. xylosus at 30, 60, and 90 days with 19,28, and 33.3 branches/plant, respectively. Similar improvements were achieved in fresh weight by B. safensis + P. stutzeri + S. xylosus inoculation (19.75 g/plant) followed by $P$. stutzeri + S. xylosus $(15.9 \mathrm{~g} /$ plant $)$ inoculation. The lowest fresh weight was observed in the stress-induced control (10 g/plant). Dry matter accumulation had been orchestrated similarly to fresh weight accumulation (Table 3). Blooming started after 30 days and a significant number of flowers was recorded with the inoculation of B. safensis $+P$. stutzeri (11.6 flowers/plant), which was on par with the monoculture treatments, S. xylosus (11.3) and B. safensis (11.3). A significant 
TABLE 2 | Influence of halophilic bacteria on plant height, root length, and number of branches of chickpea in the microcosm experiment.

\begin{tabular}{|c|c|c|c|c|c|c|c|c|c|c|c|c|c|c|c|}
\hline \multirow[t]{2}{*}{ Treatment } & \multicolumn{3}{|c|}{ Plant height (cm) } & \multicolumn{3}{|c|}{ Root length $(\mathrm{cm})$} & \multicolumn{3}{|c|}{ Number of branches } & \multicolumn{3}{|c|}{ Fresh weight (g/plant) } & \multicolumn{3}{|c|}{ Dry weight (g/plant) } \\
\hline & 30 DAS & 60 DAS & At harvest & 30 DAS & 60 DAS & At harvest & 30 DAS & 60 DAS & At harvest & Shoot & Root & Total fresh weight & Shoot & Root & Total dry weight \\
\hline \multirow[t]{2}{*}{$T_{1}$} & $10.63^{d}$ & $23.47^{\mathrm{c}}$ & $32.60^{b c}$ & $10.53^{b}$ & $13.50^{b}$ & $18.10^{\mathrm{b}}$ & $11.33^{\mathrm{c}}$ & $20.67^{a}$ & $24.33^{c}$ & 11.53 & 0.85 & $12.38^{d}$ & 4.01 & 0.62 & $4.63^{f}$ \\
\hline & $(0.07)$ & $(0.41)$ & $(0.92)$ & $(0.60)$ & $(0.36)$ & $(0.49)$ & $(1.10)$ & $(0.62)$ & $(0.58)$ & & & $(0.16)$ & & & $(0.17)$ \\
\hline \multirow[t]{2}{*}{$\mathrm{T}_{2}$} & $13.29^{c}$ & $25.63^{\mathrm{bc}}$ & $36.07^{\mathrm{ab}}$ & $12.56^{\mathrm{ab}}$ & $17.63^{\mathrm{a}}$ & $22.13^{\mathrm{ab}}$ & $13.33^{b c}$ & $23.00^{\mathrm{a}}$ & $27.33^{b c}$ & 10.96 & 0.74 & $11.70^{d}$ & 5.00 & 0.68 & $5.69^{\mathrm{de}}$ \\
\hline & $(0.33)$ & $(0.36)$ & $(0.48)$ & $(0.45)$ & $(0.49)$ & $(0.89)$ & $(0.73)$ & (0.39) & $(0.56)$ & & & $(0.09)$ & & & $(0.10)$ \\
\hline \multirow[t]{2}{*}{$T_{3}$} & $16.72^{\mathrm{a}}$ & $32.50^{\mathrm{a}}$ & $39.40^{\mathrm{a}}$ & $15.73^{\mathrm{a}}$ & $18.60^{\mathrm{a}}$ & $26.23^{a}$ & $17.67^{\mathrm{a}}$ & $27.67^{\mathrm{a}}$ & $33.33^{a}$ & 16.06 & 1.06 & $17.12^{\mathrm{a}}$ & 7.32 & 0.83 & $8.16^{a}$ \\
\hline & $(0.10)$ & $(0.70)$ & $(0.64)$ & $(0.50)$ & $(0.72)$ & $(0.62)$ & $(0.66)$ & $(0.56)$ & $(0.53)$ & & & $(0.14)$ & & & $(0.21)$ \\
\hline \multirow[t]{2}{*}{$\mathrm{T}_{4}$} & $14.30^{\mathrm{bc}}$ & $26.27^{\mathrm{bc}}$ & $30.40^{c}$ & $12.70^{\mathrm{ab}}$ & $16.46^{\mathrm{ab}}$ & $23.27^{\mathrm{ab}}$ & $16.00^{\mathrm{ab}}$ & $23.00^{\mathrm{a}}$ & $28.00^{\mathrm{bc}}$ & 15.46 & 1.02 & $16.48^{\mathrm{ab}}$ & 6.25 & 0.74 & $6.99^{b c}$ \\
\hline & $(0.22)$ & $(0.58)$ & $(0.67)$ & $(0.47)$ & $(0.56)$ & $(1.24)$ & $(0.45)$ & $(0.39)$ & $(0.36)$ & & & $(0.15)$ & & & $(0.14)$ \\
\hline \multirow[t]{2}{*}{$T_{5}$} & $13.69^{\mathrm{bc}}$ & $23.10^{c}$ & $32.13^{\mathrm{bc}}$ & $11.56^{b}$ & $17.10^{\mathrm{ab}}$ & $22.33^{\mathrm{ab}}$ & $13.00^{\mathrm{bc}}$ & $21.00^{\mathrm{a}}$ & $25.67^{c}$ & 14.43 & 1.02 & $15.45^{\mathrm{c}}$ & 4.66 & 0.78 & $5.44^{\mathrm{e}}$ \\
\hline & $(0.06)$ & $(0.21)$ & $(0.55)$ & $(0.64)$ & $(1.01)$ & $(1.12)$ & $(0.49)$ & $(0.81)$ & $(0.58)$ & & & $(0.12)$ & & & $(0.18)$ \\
\hline \multirow[t]{2}{*}{$T_{6}$} & $15.53^{\mathrm{ab}}$ & $29.20^{\mathrm{ab}}$ & $39.27^{\mathrm{a}}$ & $12.23^{\mathrm{ab}}$ & $18.53^{\mathrm{a}}$ & $23.70^{\mathrm{ab}}$ & $16.33^{\mathrm{ab}}$ & $25.67^{a}$ & $30.00^{\mathrm{ab}}$ & 15.73 & 1.02 & $16.75^{a}$ & 6.62 & 0.82 & $7.44^{\mathrm{ab}}$ \\
\hline & $(0.40)$ & $(0.59)$ & $(0.61)$ & $(0.81)$ & $(0.40)$ & $(0.76)$ & $(0.68)$ & $(0.58)$ & $(0.36)$ & & & $(0.14)$ & & & $(0.13)$ \\
\hline \multirow[t]{2}{*}{$\mathrm{T}_{7}$} & $14.6^{\mathrm{bc}}$ & $24.73^{\mathrm{C}}$ & $32.73^{\mathrm{bc}}$ & $11.10^{\mathrm{b}}$ & $16.43^{\mathrm{ab}}$ & $21.87^{\mathrm{ab}}$ & $11.67^{\circ}$ & $21.33^{\mathrm{a}}$ & $26.67^{\mathrm{bc}}$ & 14.76 & 0.94 & $15.71^{b c}$ & 5.28 & 0.68 & $5.96^{\mathrm{de}}$ \\
\hline & $(0.33)$ & $(0.38)$ & $(0.73)$ & $(1.08)$ & $(0.30)$ & $(0.84)$ & $(0.79)$ & $(1.24)$ & $(0.57)$ & & & $(0.11)$ & & & $(0.24)$ \\
\hline \multirow[t]{2}{*}{$T_{8}$} & $13.38^{\mathrm{c}}$ & $25.26^{\mathrm{bc}}$ & $33.83^{\mathrm{abc}}$ & $11.89^{\mathrm{ab}}$ & $16.53^{\mathrm{ab}}$ & $22.93^{\mathrm{ab}}$ & $14.33^{\mathrm{abc}}$ & $25.67^{\mathrm{a}}$ & $30.00^{\mathrm{ab}}$ & 15.10 & 1.42 & $16.52^{\mathrm{a}}$ & 5.50 & 0.79 & $6.28^{\mathrm{cd}}$ \\
\hline & $(0.64)$ & $(0.76)$ & $(0.84)$ & $(0.86)$ & $(0.33)$ & $(0.84)$ & $(0.71)$ & $(0.21)$ & $(0.36)$ & & & $(0.06)$ & & & $(0.27)$ \\
\hline SE (m) & 0.57 & 1.18 & 1.63 & 1.13 & 1.068 & 1.82 & 1.23 & 1.37 & 1.11 & 0.23 & 0.04 & 0.23 & 0.24 & 0.04 & 0.23 \\
\hline SE (d) & 0.40 & 0.83 & 1.15 & 0.80 & 0.755 & 1.29 & 0.87 & 0.97 & 0.78 & 0.16 & 0.03 & 0.16 & 0.17 & 0.03 & 0.16 \\
\hline C.D. at $5 \%$ & 1.21 & 2.52 & 3.49 & 2.42 & 2.283 & 3.89 & 2.62 & 2.94 & 2.36 & 0.50 & 0.09 & 0.49 & 0.52 & 0.09 & 0.49 \\
\hline
\end{tabular}

*Data are grouped based on the Tukey pairwise comparison. 


\begin{tabular}{|c|c|c|c|c|c|c|c|c|c|c|c|c|c|c|c|}
\hline \multirow[t]{2}{*}{ Treatment } & \multicolumn{3}{|c|}{ Plant height $(\mathrm{cm})$} & \multicolumn{3}{|c|}{ Root length } & \multicolumn{3}{|c|}{ Number of branches } & \multicolumn{3}{|c|}{ Fresh weight (g/plant) } & \multicolumn{3}{|c|}{ Dry weight (g/plant) } \\
\hline & 30 DAS & 60 DAS & At harvest & Shoot & Shoot & Shoot & 30 DAS & 60 DAS & At harvest & Shoot & Root & Total fresh weight & Shoot & Root & Total Dry weigh \\
\hline \multirow{2}{*}{$\begin{array}{l}\text { Uninoculated } \\
\text { Control (No stress) }\end{array}$} & $9.64^{a}$ & $23.46^{\mathrm{c}}$ & $41.66^{\mathrm{abc}}$ & 12.00 & 12.00 & 12.00 & $10.33^{\mathrm{de}}$ & $18.66^{c d}$ & $18.66^{b c}$ & 12.00 & 0.76 & $12.76^{b}$ & 5.68 & 0.24 & $5.92^{\mathrm{cd}}$ \\
\hline & $(0.60)$ & $(0.61)$ & $(1.20)$ & $(0.57)$ & $(0.57)$ & $(0.57)$ & $(1.20)$ & $(0.88)$ & $(0.88)$ & $(0.57)$ & $(0.009)$ & $(0.57)$ & $(0.61)$ & $(0.02)$ & $(0.59)$ \\
\hline \multirow{2}{*}{$\begin{array}{l}\text { Uninoculated } \\
\text { Control }\left(4 \mathrm{dSm}^{-1}\right)\end{array}$} & $8.72^{\mathrm{a}}$ & $25.63^{b c}$ & $33.00^{\mathrm{c}}$ & 10.00 & 10.00 & 10.00 & $7.00^{\mathrm{e}}$ & $16.66^{d}$ & $16.66^{c}$ & 10.00 & 0.68 & $10.68^{b}$ & 4.48 & 0.20 & $4.68^{d}$ \\
\hline & $(0.74)$ & $(0.56)$ & (1.52) & $(0.57)$ & $(0.57)$ & $(0.57)$ & $(0.57)$ & $(0.88)$ & $(0.88)$ & $(0.57)$ & $(0.01)$ & $(0.58)$ & $(0.81)$ & $(0.01)$ & $(0.80)$ \\
\hline \multirow[t]{2}{*}{ Bacillus safensis } & $10.83^{a}$ & $29.66^{\mathrm{ab}}$ & $39.33^{\mathrm{abc}}$ & 14.33 & 14.33 & 14.33 & $13.66^{\mathrm{bcd}}$ & $24.33^{\mathrm{ab}}$ & $24.33^{\mathrm{a}}$ & 14.33 & 1.15 & $15.49^{\mathrm{ab}}$ & 7.96 & 0.42 & $8.38^{\mathrm{abc}}$ \\
\hline & $(0.50)$ & $(0.92)$ & $(5.20)$ & $(0.88)$ & $(0.88)$ & $(0.88)$ & $(0.88)$ & $(0.88)$ & $(0.88)$ & $(0.88)$ & $(0.12)$ & $(0.98)$ & $(0.66)$ & $(0.04)$ & $(0.70)$ \\
\hline \multirow{2}{*}{$\begin{array}{l}\text { Pseudomonas } \\
\text { stutzeri isolate } 1\end{array}$} & $10.21^{\mathrm{a}}$ & $29.50^{\mathrm{ab}}$ & $38.66^{\mathrm{abc}}$ & 11.33 & 11.33 & 11.33 & $11.66^{\text {cde }}$ & $22.66^{b c}$ & $22.66^{b c}$ & 11.33 & 0.78 & $12.11^{\mathrm{b}}$ & 6.17 & 0.26 & $6.43^{b c d}$ \\
\hline & $(0.45)$ & $(0.95)$ & $(1.76)$ & $(0.88)$ & $(0.88)$ & $(0.88)$ & $(0.88)$ & $(1.20)$ & $(1.20)$ & $(0.88)$ & $(0.01)$ & $(0.86)$ & $(0.73)$ & (0.02) & $(0.72)$ \\
\hline \multirow{2}{*}{$\begin{array}{l}\text { Staphylococcus } \\
\text { xylosus }\end{array}$} & $9.03^{a}$ & $23.86^{c}$ & $37.33^{b c}$ & 12.33 & 12.33 & 12.33 & $12.66^{\mathrm{bcd}}$ & $23.66^{b}$ & $23.66^{c}$ & 12.33 & 1.01 & $13.35^{b}$ & 5.73 & 0.36 & $6.09^{c d}$ \\
\hline & $(1.26)$ & $(0.87)$ & $(1.20)$ & $(0.88)$ & $(0.88)$ & $(0.88)$ & $(0.88)$ & $(0.88)$ & $(0.88)$ & $(0.88)$ & $(0.03)$ & $(0.87)$ & $(0.11)$ & (0.02) & $(0.13)$ \\
\hline \multirow{2}{*}{$\begin{array}{l}\text { B. safensis + } \\
\text { P. stutzeri }\end{array}$} & $10.10^{\mathrm{a}}$ & $32.83^{a}$ & $40.33^{\mathrm{abc}}$ & 13.00 & 13.00 & 13.00 & $17.33^{\mathrm{ab}}$ & $26.66^{a b}$ & $26.66^{a}$ & 13.00 & 0.83 & $13.83^{b}$ & 7.41 & 0.29 & $7.69^{\mathrm{abc}}$ \\
\hline & $(0.34)$ & (1.31) & $(1.20)$ & (1.52) & $(1.52)$ & $(1.52)$ & $(0.88)$ & $(0.88)$ & $(0.88)$ & $(1.52)$ & $(0.009)$ & (1.53) & $(0.16)$ & $(0.02)$ & $(0.15)$ \\
\hline \multirow{2}{*}{$\begin{array}{l}\text { P. stutzeri + } \\
\text { S. xylosus }\end{array}$} & $9.59^{a}$ & $29.76^{a b}$ & $44.66^{a b}$ & 15.00 & 15.00 & 15.00 & $15.33^{\mathrm{abc}}$ & $24.66^{\mathrm{ab}}$ & $24.66^{\mathrm{ab}}$ & 15.00 & 0.94 & $15.94^{\mathrm{ab}}$ & 8.28 & 0.71 & $8.99^{\mathrm{ab}}$ \\
\hline & $(0.67)$ & $(0.80)$ & $(1.76)$ & $(0.57)$ & $(0.57)$ & $(0.57)$ & $(1.45)$ & $(0.88)$ & $(0.88)$ & $(0.57)$ & $(0.01)$ & $(0.58)$ & $(0.66)$ & $(0.02)$ & $(0.68)$ \\
\hline \multirow{2}{*}{$\begin{array}{l}\text { B. safensis + } \\
\text { P. stutzeri + } \\
\text { S. xylosus }\end{array}$} & $10.95^{\mathrm{a}}$ & $34.03^{\mathrm{a}}$ & $48.66^{a}$ & 18.33 & 18.33 & 18.33 & $19.00^{a}$ & $28.66^{a}$ & $28.66^{a}$ & 18.33 & 1.42 & $19.75^{a}$ & 8.60 & 0.68 & $9.27^{\mathrm{a}}$ \\
\hline & $(1.25)$ & $(0.98)$ & $(1.76)$ & $(1.76)$ & $(1.76)$ & $(1.76)$ & $(1.15)$ & $(0.88)$ & $(0.88)$ & $(1.76)$ & $(0.05)$ & $(1.76)$ & $(0.19)$ & $(0.02)$ & $(0.19)$ \\
\hline \multirow{2}{*}{$\begin{array}{l}\text { Pseudomonas Sp. } \\
\text { (reference strain) }\end{array}$} & $9.56^{a}$ & $31.00^{a}$ & $42.33^{\mathrm{abc}}$ & 14.66 & 14.66 & 14.66 & $14.00^{\mathrm{bcd}}$ & $26.66^{\mathrm{ab}}$ & $26.66^{a}$ & 14.66 & 0.81 & $15.48^{\mathrm{ab}}$ & 8.01 & 0.29 & $8.29^{\mathrm{abc}}$ \\
\hline & $(0.95)$ & $(1.47)$ & $(1.45)$ & $(1.20)$ & $(1.20)$ & $(1.20)$ & $(0.57)$ & $(0.88)$ & $(0.88)$ & $(1.20)$ & $(0.01)$ & (1.18) & $(0.11)$ & $(0.01)$ & $(0.10)$ \\
\hline SE(m) & 0.841 & 1.037 & 2.201 & 1.087 & 1.087 & 1.087 & 0.969 & 0.904 & 0.904 & 1.087 & 0.05 & 1.09 & 1.68 & 0.07 & 1.69 \\
\hline$S E(d)$ & 1.189 & 1.466 & 3.112 & 1.537 & 1.537 & 1.537 & 1.371 & 1.279 & 1.279 & 1.537 & 0.071 & 1.55 & 0.56 & 0.02 & 0.56 \\
\hline C.D. at $5 \%$ & 2.523 & 3.135 & 6.654 & 3.285 & 3.285 & 3.285 & 2.931 & 2.735 & 2.735 & 3.285 & 0.151 & 3.31 & 0.79 & 0.03 & 0.79 \\
\hline
\end{tabular}

"Data are grouped based on the Tukey pairwise comparison. 
TABLE 4 | Influence of halophilic bacteria on nutrient uptake and yield parameters of chickpea under field conditions.

\begin{tabular}{|c|c|c|c|c|c|c|c|c|c|c|c|}
\hline \multirow[t]{2}{*}{ Treatment } & \multicolumn{2}{|c|}{ Number of flowers } & \multicolumn{2}{|c|}{ Number of pods } & \multirow{2}{*}{$\begin{array}{c}\text { Number of nodules } \\
60 \text { DAS }\end{array}$} & \multirow{2}{*}{$\begin{array}{c}\text { N (\%) } \\
\text { (Mean } \pm \text { S.E.) }\end{array}$} & \multirow{2}{*}{$\begin{array}{c}\text { N-uptake } \\
\text { (Mean } \pm \text { S.E.) }\end{array}$} & \multirow{2}{*}{$\begin{array}{c}\mathbf{P}(\%) \\
\text { (Mean } \pm \text { S.E.) }\end{array}$} & \multirow{2}{*}{$\begin{array}{c}\text { P-uptake } \\
\text { (Mean } \pm \text { S.E.) }\end{array}$} & \multirow[t]{2}{*}{ K-uptake } & \multirow[t]{2}{*}{ Yield (q/ha) } \\
\hline & 30 DAS & 60 DAS & 60 DAS & At harvest & & & & & & & \\
\hline \multirow[t]{2}{*}{ Uninoculated Control (No stress) } & $7.67^{\mathrm{ab}}$ & $35.67^{d}$ & $39.66^{\mathrm{ef}}$ & $57.66^{e}$ & $4.33^{\mathrm{c}}$ & $1.14 \pm 0.11$ & $47.86 \pm 2.51$ & $0.337 \pm 0.003$ & $14.40 \pm 0.66$ & 80.43 & 9.56 \\
\hline & $(0.33)$ & $(1.76)$ & $(2.33)$ & $(2.72)$ & $(0.33)$ & & & & & & \\
\hline \multirow[t]{2}{*}{ Uninoculated Control (4 $\left.\mathrm{dS} \mathrm{m}^{-1}\right)$} & $6.00^{\mathrm{b}}$ & $29.33^{d}$ & $36.00^{f}$ & $42.33^{\dagger}$ & $4.67^{\mathrm{C}}$ & $1.13 \pm 0.05$ & $40.57 \pm 3.95$ & $0.35 \pm 0.000$ & $12.43 \pm 0.66$ & 119.81 & 9.22 \\
\hline & $(0.58)$ & $(1.45)$ & $(2.64)$ & $(2.02)$ & $(0.88)$ & & & & & & \\
\hline \multirow[t]{2}{*}{ Bacillus safensis } & $11.33^{\mathrm{a}}$ & $68.33^{\mathrm{a}}$ & $59.33^{\mathrm{cd}}$ & $74.00^{\mathrm{bcd}}$ & $9.33^{\mathrm{ab}}$ & $1.29 \pm 0.09$ & $66.49 \pm 4.51$ & $0.35 \pm 0.000$ & $18.13 \pm 1.16$ & 160.06 & 10.44 \\
\hline & $(0.88)$ & $(3.48)$ & $(3.75)$ & $(1.73)$ & $(0.33)$ & & & & & & \\
\hline \multirow[t]{2}{*}{ Pseudomonas stutzeri isolate 1} & $8.67^{\mathrm{ab}}$ & $48.67^{\mathrm{C}}$ & $47.00^{\text {def }}$ & $63.00^{\text {de }}$ & $5.00^{\mathrm{c}}$ & $1.44 \pm 0.07$ & $58.36 \pm 6.79$ & $0.33 \pm 0.000$ & $13.44 \pm 0.94$ & 169.43 & 9.78 \\
\hline & $(0.33)$ & $(2.60)$ & $(2.08)$ & $(2.30)$ & $(1.16)$ & & & & & & \\
\hline \multirow[t]{2}{*}{ Staphylococcus xylosus } & $11.33^{\mathrm{a}}$ & $55.00^{\mathrm{bc}}$ & $49.33^{\text {de }}$ & $71.00^{\mathrm{cd}}$ & $6.33^{b c}$ & $1.10 \pm 0.05$ & $48.95 \pm 3.34$ & $0.31 \pm 0.000$ & $13.75 \pm 0.91$ & 204.08 & 9.44 \\
\hline & $(0.88)$ & $(1.16)$ & $(1.45)$ & $(2.30)$ & $(0.33)$ & & & & & & \\
\hline \multirow[t]{2}{*}{ B. safensis $+P$. stutzeri } & $11.67^{\mathrm{a}}$ & $71.67^{\mathrm{a}}$ & $76.33^{\mathrm{ab}}$ & $91.33^{\mathrm{a}}$ & $10.00^{\mathrm{a}}$ & $1.52 \pm 0.11$ & $70.89 \pm 12.22$ & $0.28 \pm 0.003$ & $13.07 \pm 1.43$ & 230.74 & 10.89 \\
\hline & $(1.20)$ & $(2.60)$ & $(1.45)$ & $(2.33)$ & $(0.58)$ & & & & & & \\
\hline \multirow[t]{2}{*}{ P. stutzeri + S. xylosus } & $10.33^{a}$ & $64.67^{\mathrm{ab}}$ & $69.33^{\mathrm{abc}}$ & $84.00^{\mathrm{ab}}$ & $7.33^{\mathrm{abc}}$ & $1.15 \pm 0.09$ & $60.40 \pm 2.94$ & $0.33 \pm 0.000$ & $17.78 \pm 0.66$ & 210.66 & 10.22 \\
\hline & $(0.88)$ & $(2.03)$ & $(3.18)$ & $(2.64)$ & $(0.88)$ & & & & & & \\
\hline \multirow[t]{2}{*}{ B. safensis + P. stutzeri + S. xylosus } & $10.33^{\mathrm{a}}$ & $75.00^{\mathrm{a}}$ & $78.66^{\mathrm{a}}$ & $91.66^{a}$ & $9.67^{\mathrm{ab}}$ & $1.18 \pm 0.05$ & $78.14 \pm 9.24$ & $0.31 \pm 0.003$ & $20.02 \pm 1.66$ & 243.12 & 11.22 \\
\hline & $(1.20)$ & $(1.16)$ & $(2.90)$ & $(2.90)$ & $(0.67)$ & & & & & & \\
\hline \multirow[t]{2}{*}{ Pseudomonas Sp. (reference strain) } & $10.67^{a}$ & $66.33^{a}$ & $65.66^{\mathrm{bc}}$ & $82.00^{a b c}$ & $7.67^{a b c}$ & $1.27 \pm 0.06$ & $65.53 \pm 4.36$ & $0.32 \pm 0.003$ & $16.76 \pm 1.33$ & 174.29 & 10.33 \\
\hline & $(0.88)$ & $(1.45)$ & $(1.76)$ & $(2.51)$ & $(0.33)$ & & & & & & \\
\hline SE $(m)$ & 0.83 & 2.14 & 1.99 & 2.53 & 0.66 & 0.10 & 9.07 & 0.0006 & 1.58 & 14.39 & 0.127 \\
\hline SE (d) & 1.18 & 3.02 & 2.82 & 3.58 & 0.93 & 0.07 & 6.42 & 0.00 & 1.12 & 13.75 & 0.179 \\
\hline C.D. at $5 \%$ & 2.51 & 6.47 & 6.03 & 7.66 & 1.99 & 0.21 & 19.40 & 0.016 & 3.39 & 43.24 & 0.381 \\
\hline
\end{tabular}




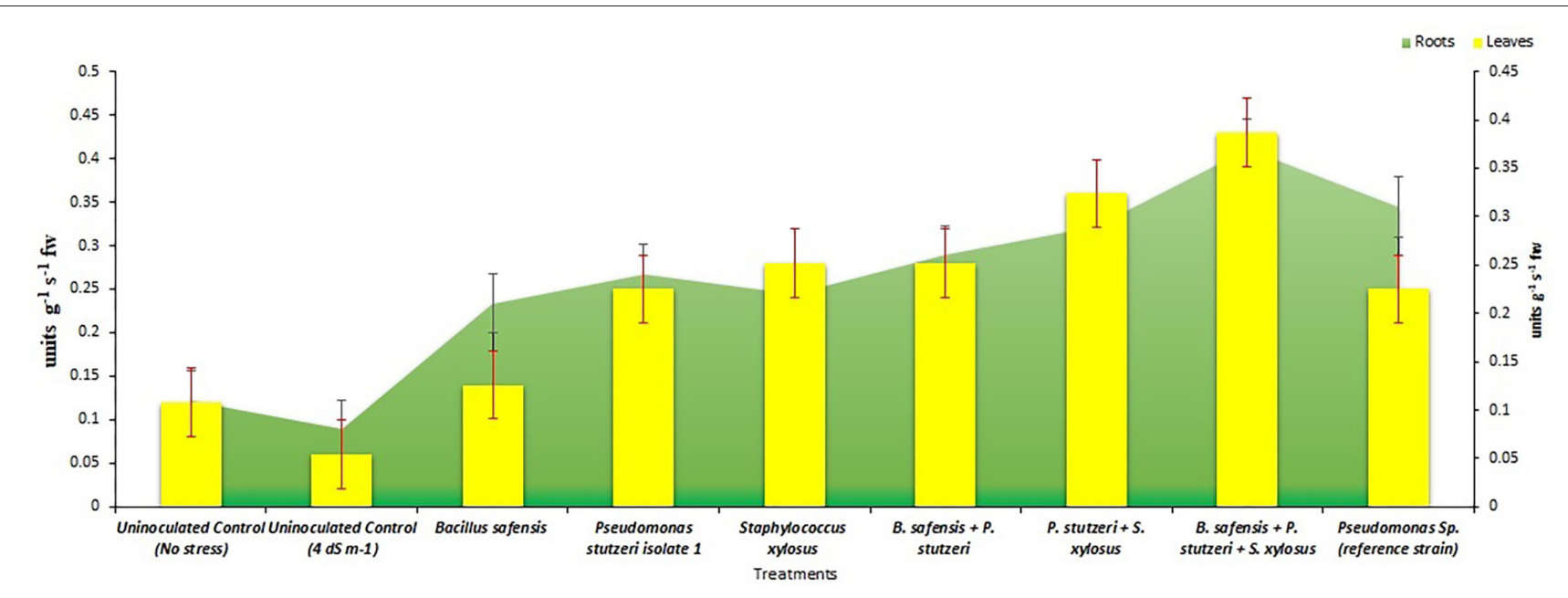

FIGURE 3 | Superoxide dismutase activity in the roots and leaves of chickpea: the roots of chickpeas have more superoxide dismutase activity than the leaves. The plants inoculated by the consortium had the highest superoxide dismutase activity.

number of flowers (75 flowers/plant) and pods (91.6 pods/plant) was observed with the treatment of $B$. safensis + P. stutzeri + $S$. xylosus. Nodulation was noticed in the field experiment; $B$. safensis $+P$. stutzeri treatment showed 10 nodules/plant followed by $B$. safensis + P. stutzeri + S. xylosus (9.6 nodules/plant) and the data are shown in Table 4. Nutrient uptake and biomass yield enhancement by consortium treatment reflected the achievement of maximum grain yield of $11.22 \mathrm{q} /$ ha followed by B. safensis and P. stutzeri treatment (10.89 q/ha) (Table 4). The results suggest that a consortium of $B$. safensis $+P$. stutzeri $+S$. xylosus can mitigate the adverse effects of salinity on the growth and yield of chickpea.

\section{Antioxidant Enzymes Activity and Proline Content}

Under salinity stress, SOD, CAT, and ascorbate peroxidase activity were increased with the treatment of halophilic bacteria. The consortium of halophilic bacterial isolates improved the SOD, CAT, and ascorbate peroxidase activities by treated plants over the control. The SOD activity was more in leaves, which was $258 \%$ higher in consortium-treated plants than in the control treatment (Figure 3). Similarly, CAT was reported highest in leaves of the consortium, which was $196 \%$ higher than the control treatment (Figure 4). Ascorbate peroxidase activity was maximum in leaves; consortium treatment showed $0.41 \mu \mathrm{mol}$ of ascorbate oxidized $\mathrm{s}^{-1} \mathrm{~g}^{-1}$ fresh weight (Figure 5). The proline content was increased in the salt stress-induced plants and maximum proline content was recorded in consortium treatment (14.84 $\mu \mathrm{mol} \mathrm{g}^{-1}$ of fresh weight).

\section{DISCUSSION}

1-aminocyclopropane-1-carboxylate deaminase activity is one of the critical growth-stimulating traits required under the stress in plants (Ahmad et al., 2011). ACC deaminase is a pyridoxal phosphate-dependent and inducible enzyme that breaks the
ACC, an intermediate precursor for ethylene production in plants, into ammonia and $\alpha$-ketoglutarate by opening the cyclopropane ring (Honma and Shimomura, 1978). The enzyme was first purified from the Pseudomonas spp. strain ACP (Klee et al., 1991) and size varies from 110 to $112 \mathrm{kDa}$; it is a trimetric enzyme with an approximate subunit mass of 36,500 Da. This enzyme activity can be observed in the $\mathrm{pH}$ range of 8.0-8.5 (Zhao et al., 2003). In this study, seven halophilic bacteria with high ACC deaminase activity $(0.12-3.56 \mathrm{mM}$ $\alpha \mathrm{KB} \mathrm{mg} \mathrm{min}^{-1}$ ) were used to assess the growth and yield promotion of chickpea under saline conditions. They were also reported to change the $\mathrm{pH}$ and $\mathrm{EC}$ of the rhizosphere, i.e., reduction of $\mathrm{pH}$ and $\mathrm{EC}$ were recorded as 12.31 and $17.96 \%$, respectively, with the inoculation of $B$. safensis. The decrease in $\mathrm{pH}$ and $\mathrm{EC}$ of rhizosphere was maximum at 60 days in the microcosm experiment. Changes in $\mathrm{pH}$ and $\mathrm{EC}$ of rhizosphere were attributed to rhizodeposition, microbial, and plant acid production near the root zone (Guihua et al., 2018). Rhizosphere $\mathrm{pH}$ alteration under severe nutrient stress by dissolved organic acids from plant root exudates was well documented (Etesami et al., 2014). After 75 days of seeding, all of the treatments showed a modest and consistent increase in $\mathrm{pH}$ and EC. Facultative anaerobes produce several organic acids in soil, viz., fumaric, maleic, lactic, butyric, propionic, and citric acids [lowmolecular-weight organic acids (LMWOAs)] and most of them are byproducts or products of the tricarboxylic acid (TCA) cycle (Takeno et al., 2007). These LMWOAs are more soluble in water and differ in their interaction of oxygen, carbon, and hydrogen elements. In this study, a change in color from green to yellow of soil solution with bromothymol blue was recorded, i.e., indicating a decrease in $\mathrm{pH}$. Organic acids in soil solution typically range between 0 and $50 \mu \mathrm{M}$ for di-/TCAs and from 0 to $1 \mu \mathrm{m}$ for monocarboxylic acids (Strobel, 2001). There is an unimaginable thrust in the root zone for nutrients under saline conditions, since many soluble salts create a nutrient deficiency. $\mathrm{N}$ and $\mathrm{P}$ uptake of a plant depends on the physical and genetic 


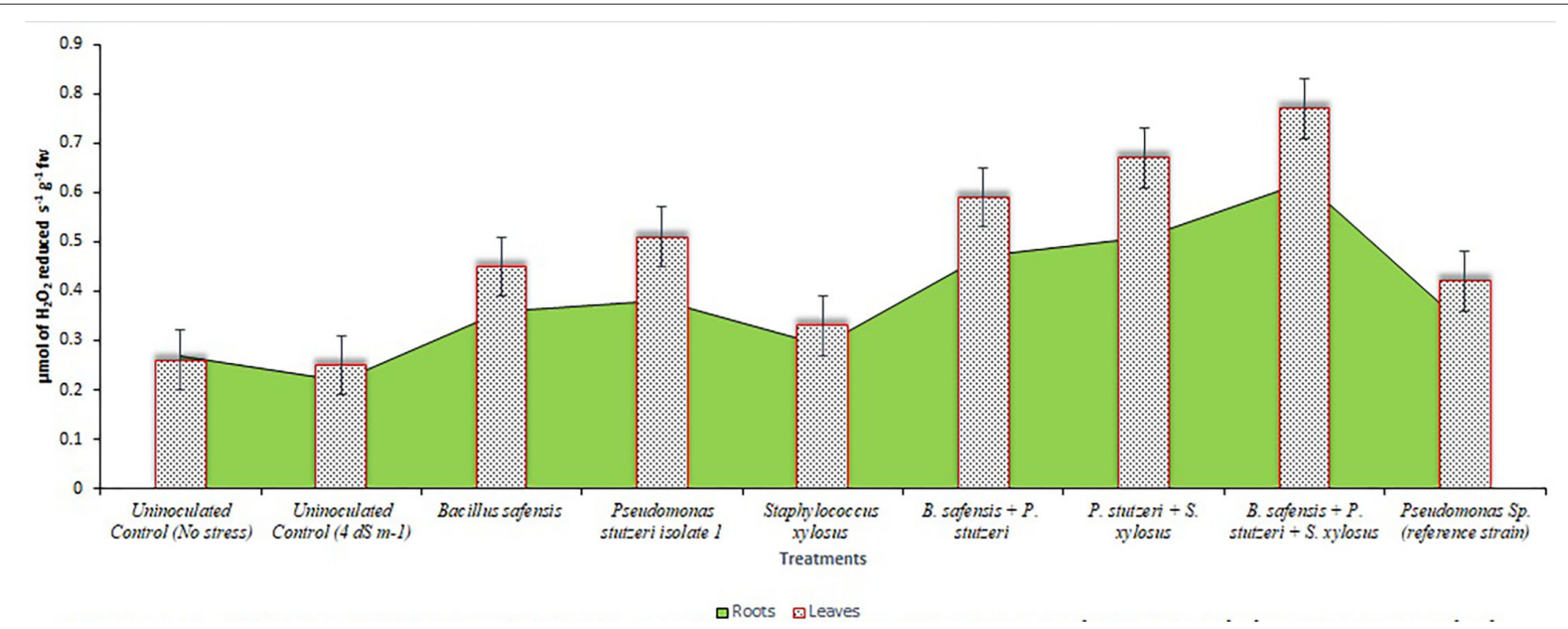

FIGURE 4 | Catalase (CAT) activity in roots and leaves: leaves had more pronounced CAT activity than roots, and consortium treatment had the greatest catalase activity.

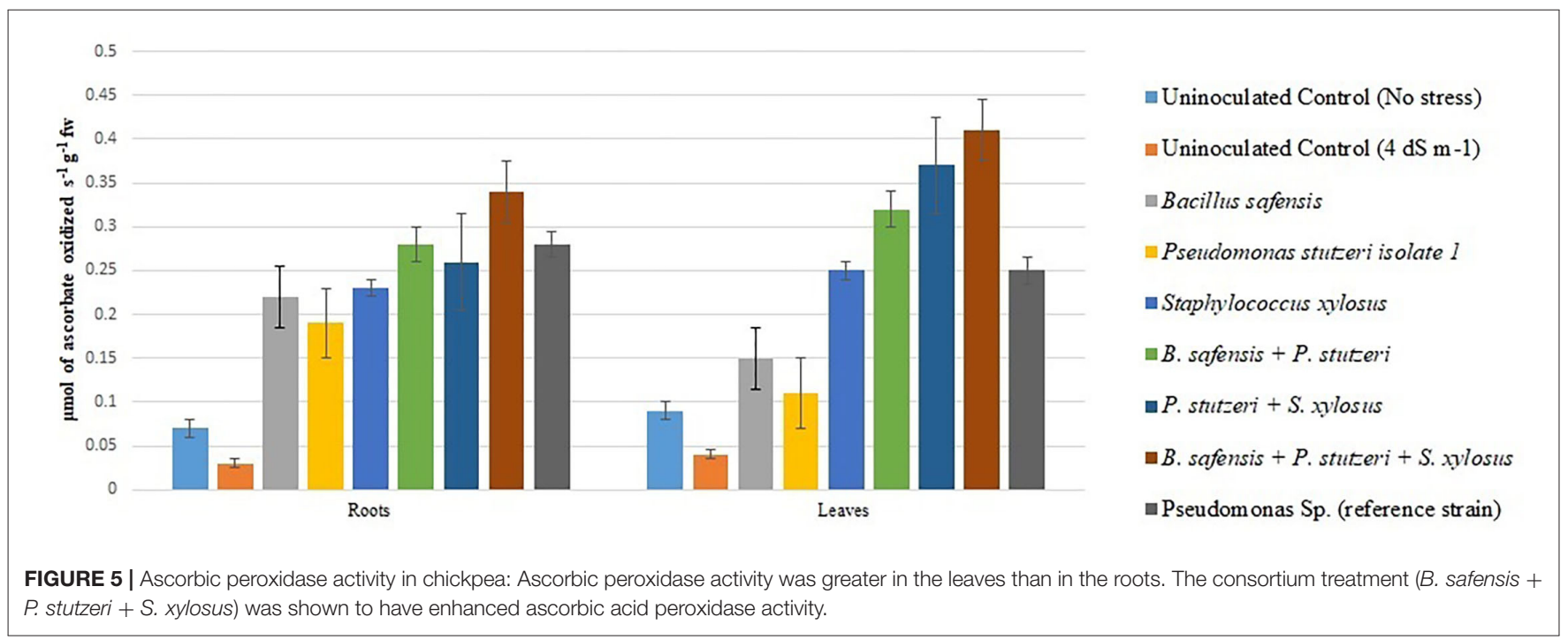

factors; higher yielding genotypes uptake more amounts of $\mathrm{N}$ and P (Rao et al., 2002).

However, sufficient nutrient uptake ( $\mathrm{N}$ and $\mathrm{P}$ ) was observed in B. safensis-treated plants. Similarly, increased N and P uptake with the inoculation of Bacillus pumilus was noticed in wheat at 60 and 90 days when compared with control plants (Upadhyay and Singh, 2014). The phosphate solubilizers and Rhizobium application enhanced the nitrogen and phosphorus uptake of chickpea (Gangwar and Dubey, 2012). PGPR solubilizes and mobilizes the nutrients by producing organic acids and improving the water use efficiency and physiological and biochemical changes in plants (Mukherjee et al., 2019). oxalic acid (OA) solubilizes and mobilizes $\mathrm{Fe}, \mathrm{K}, \mathrm{P}$, and $\mathrm{Mg}$ containing minerals by forming a strong bond with mineral ions, transferring electrons, or breaking the oxygen links of the complex minerals (Uroz et al., 2009; Kang et al., 2014). They also play a crucial role in the carbon cycle and detoxification of heavy metals in the rhizosphere (Adeleke et al., 2017). PGPHB enhanced nutrient availability reflected in growth of chickpea, yield, individual inoculations of $B$. safensis and $S$. xylosus, increased plant height, root length, number of branches, number of flowers, number of pods, and grain yield when compared to control. B. safensis is positive for ACC deaminase, acid production, and a potential potassium releaser. S. xylosus also have zinc solubilization capacity at $10 \% \mathrm{NaCl}$ concentration. Similarly, inoculation with B. safensis enhanced soybean and wheat growth. Salt stress significantly reduced the plant height in chickpea at higher salinity (Seyoum and Diriba, 2017). The decrease in shoot length was observed in the uninoculated control ascribed to the poor availability of water or increased $\mathrm{NaCl}$ concentration (Munns and James, 2003). Inoculation with Rhizobium enhanced the growth of chickpea up to $19 \%$ at 3.3-7.4 dS $\mathrm{m}^{-1}$ salinity. Root length was enhanced with the individual inoculations of B. safensis, S.xylosus, and $P$. 
stutzeri in the decreasing order. Inoculation of PGPR enhances the plant growth attributed to the biosynthesis and secretion of IAA near the root zone (Patten and Glick, 1996; Qin et al., 2016). Production of IAA by several PGPR bacteria enhances the root length and proliferation (Spaepen et al., 2007). However, the IAA concentration plays a key role, i.e., it can promote growth at low concentrations, whereas high concentration inhibits the development. Increased root length was attributed to the micronutrient availability (Subramaniam et al., 2016). Application of phosphorus increases the plant height, root nodules, number of branches, and dry matter accumulation. Significant yield enhancement was reported with the treatment of $S$. xylosus in chickpea. Exopolysaccharides production by $S$. xylosus enhanced soil aggregate formation in the presence of salts (Qurashi and Sabri, 2013). In turn, polysaccharides production enhances biofilm formation, enhancing the survivability of microorganisms in the salinity stress. Increased exopolysaccharide production and biofilm formation with an increase in salinity were evidenced in the isolates such as Halomonas variabilis and Planococcus rifietoensis. Accumulation of osmolytes, viz., proline, glycine, betaine, and choline in moderately halophilic bacteria B. subtilis and $S$. haemolyticus and their inoculation to chickpea enhance the growth under salinity stress (Qurashi and Sabri, 2013). Based on the microcosm study and previous findings, three (B. safensis, P. stutzeri, and S. xylosus) ACC deaminase positive were selected for the field study.

In this field study, consortium performed better than the individual inoculation and shoot length was significant with the coinoculation of $B$. safensis, P. stutzeri, and S. xylosus at 30, 60 days, and harvest. Root length was maximum at harvest with the earlier treatment. Seed inoculation with Bacillus spp. increased the shoot and root growth of chickpea by excluding the considerable amounts of $\mathrm{Na}^{+}$ions out of the cell (Munns and Tester, 2008). The decrease in root length was observed in control; nonavailability of nutrients and carbon for growth might hamper the growth (Cheesman, 1988). In saline soils, the preponderance of nonessential elements makes the essential elements unavailable (Fageria et al., 2011). The nitrogen uptake can be enhanced by dressing fertilization in chickpea (Ahmet et al., 2018). Inoculation with Bacillus spp. enhanced the plant growth by increased $\mathrm{P}$ uptake. Nutrient uptake (N and $\mathrm{P}$ ) was observed maximum with the coinoculation of B. safensis, P. stutzeri, and S. xylosus; the release of fixed minerals by microbial and plant-produced organic acids might enhance nutrient uptake under salinity stress (Toro et al., 1997). Halophilic bacteria deploy the siderophores, which will scavenge the iron and few other micronutrients $(\mathrm{Zn}, \mathrm{Ca}, \mathrm{Cu}$, $\mathrm{Mn}$, and $\mathrm{Mg}$ ) required for the growth of plant (Sathya et al., 2017), which improves the plant growth considerably. Fresh weight and dry weight were significantly enhanced under salinity with the coinoculation of B. safensis, P. stutzeri, S. xylosus, and monoinoculation of $B$. safensis. Solubilization of insoluble phosphorus and IAA production by $B$. safensis might enhance the fresh and dry weight of chickpea.

In addition, increased water availability and nutrient content under salinity conditions promoted the fresh weight of chickpea (Subramaniam et al., 2016). An increase in the fresh weight of wheat and soybean was also observed. Reduction of dry weight was inconspicuous under low salt stress, whereas it was observed at higher salinity; negative results were also reported at $200 \mathrm{mM}$ $\mathrm{NaCl}$ concentration (Sathya et al., 2017).

Control $\left(4 \mathrm{dS} \mathrm{m}^{-1}\right)$ showed a significantly smaller number of flowers. Salinity severely reduces the number of flowers; $\mathrm{Na}^{+}$ ions adverse effects were observed (Yousef et al., 2008). Similarly, progressive reduction in the number of flowers with increased salinity in desi chickpea due to the suppression of growth at higher salinity during early developmental stages. This study noticed the flowering delay, which may occur differently with increased salinity in different cultivars. The number of flowers was maximum in coinoculated treatment. However, increased numbers can also be found in resistant cultivars than susceptible cultivars of chickpea (Dhingra and Varghese, 1993). The number of flowers and the number of pods were coherently affiliated with each other. Salinity stress decreased the number of pods in desi cultivars that was more pronounced than kabuli type (Neera and Ranju, 2006).

In contrast to the microcosm experiment, nodulation was observed under field conditions and native Rhizobium spp. induced nodulation. Under nonsaline conditions, three times, a more significant number of nodules was found over saline soils (Rao et al., 2002). In contrast, nodulation does not affect chickpea by salinity. The selection of efficient nodulating plants showed more nodules per plant (Rao et al., 2002). Sterilized soil was utilized to fill in the pots; moreover, no Rhizobium inoculation was made throughout the investigation, attributed to a lack of nodulation.

Conversely, nodulation was observed in the field study, which may be attributed to promoting native Rhizobium spp. by the consortium. Increased nodulation was marked with the inoculation of PGP bacteria in chickpea (Subramaniam et al., 2016). The dry weight of nodules was enhanced by the coinoculation of Azospirillum spp., Azotobacter chroococum, Mesorhizobium ciceri, and Pseudomonas fluorescens (Asad and Vafa, 2011). Seed bacterization using Bacillus spp. enhances the plant growth and yield in different crops, viz., canola (Bertrand et al., 2001), soybean (Halverson and Handelsman, 1991), and pigeon pea (Podile, 1995). This study suggests that ACC deaminase-positive fermentative halophilic bacterial consortium application enhances plant growth and yield under saline conditions. However, further study is necessary to understand the critical genes involved in regulating plant stress and metabolism.

\section{DATA AVAILABILITY STATEMENT}

The datasets presented in this study can be found in NCBI-GenBank online repositories. The names of the NCBIGenBank and accession numbers (MN098871.1, MN121550.1, MN098847.1, MZ413352, MZ413353, and MZ413354) can be found in the article.

\section{AUTHOR CONTRIBUTIONS}

YN carried out the experiment under the guidance of MS. NN, KN, KS, and SG helped in manuscript 
preparation, statistical analysis, and interpretation. All authors contributed to the article and approved the submitted version.

\section{FUNDING}

This research was part of YN's Ph.D. thesis supported by the Department of Agricultural Microbiology, University of Agricultural Sciences, Raichur, Karnataka, India, (584104). The authors acknowledge ICAR for providing (F.No. EDN/1/27/2015/SRF-Exam cell,

\section{REFERENCES}

Adeleke, R., Nwangburuka, C., and Oboirien, B. (2017). Origins, roles and fate of organic acids in soils: a review. South African J. Bot. 108, 393-406. doi: 10.1016/j.sajb.2016.09.002

Ahmad, M., Zahir, A., Naeem Asghar, H., and Asghar, M., (2011). Inducing salt tolerance in mung bean through coinoculation with rhizobia and plant-growth-promoting rhizobacteria containing 1-aminocyclopropane-1carboxylate deaminase. Can. J. Microbiol. 57, 578-589.

Ahmet, D., Hasan, D., Tolga, K., Hesna, P., Mustafa, G., and Ali, C. (2018). Yield and nutrient uptake improvement of chickpea (Cicer arietinum L.) by dressing fertilization and nitrogen doses. Sciendo 2018, 51-57. doi: 10.2478/alife-2018-0008

Ali, S. Z., Shya, V., and Rao, L. V. (2014). Isolation characterization of drought-tolerant ACC deaminase exopolysaccharide-producing fluorescent Pseudomonas sp. Ann. Microbiol. 5, 493-502. doi: 10.1007/s13213-013-0680-3

Ansari, F. A., Ahmad, I., and Pichtel, J. (2019). Growth stimulation and alleviation of salinity stress to wheat by the biofilm-forming Bacillus pumilus strain FAB10. Appl. Soil Ecol. 143, 45-54. doi: 10.1016/j.apsoil.2019.05.023

Aono, M., Sajio, H., Fujiyama, K., Sugita, M., Kondo, N., and Tanaka, K. (1995). Decrease in activity of glutathione reductase enhances paraquat sensitivity in transgenic Nicotiana tabacum. Plant Physiol. 107, 645-648. doi: $10.1104 /$ pp.107.2.645

Asad, R., and Vafa, T. (2011). Nutrient uptake and yield of chickpea (Cicer arietinum L.) inoculated with plant growth promoting rhizobacteria. Aust. J. Crop Sci. 5, 44-48. doi: 10.3316/INFORMIT.834515864889363

Ashraf, M., and McNeilly, T. (2004). Salinity tolerance in Brassica oilseeds. Critical Rev Plant Sci. 23, 157-174. doi: 10.1080/07352680490433286

Atieno, J., Li, Y., Langridge, P., Kate, D., Chris, B., Bettina, B., Rajeev, K., and Varshney, T. S. (2017). Exploring genetic variation for salinity tolerance in chickpea using image-based phenotyping. Sci. Rep. 7:1300. doi: 10.1038/s41598-017-01211-7

Barassi, C. A., Ayrault, G., Creus, C. M., Sueldo, R. J., and Sobero, M. T. (2006). Seed inoculation with Azospirillum mitigates $\mathrm{NaCl}$ effects on lettuce. Sci. Horticult. 109, 8-14. doi: 10.1016/j.scienta.2006.02.025

Bates, L. S., Waldren, R. P., and Teare, I. D. (1973). Rapid determination of free proline for water-stress studies. Plant Soil 39, 205-207. doi: 10.1007/BF00018060

Bertrand, H., Nalin, R., Bally, R., and Cleyet, M. J. C. (2001). Isolation and identification of the most efficient plant growth promoting bacteria associated with canola (Brassica napus). Biol. Fer. Soil 33, 152-156. doi: $10.1007 / \mathrm{s} 003740000305$

Boursiac, Y., Chen, S., Luu, D. T., Sorieul, M., Dries, N. V. D., and Maurel, C. (2005). Early effects of salinity on water transport in Arabidopsis roots. Molecular and cellular features of aquaporin expression. Plant Phys. 139, 790-805, doi: 10.1104/pp.105.065029

Campbell, M. T., Knecht, A. C., Berger, B., Brien, C. J., Wang, D., and Walia, H. (2015). Integrating image-based phenomics and association analysis to dissect the genetic architecture of temporal salinity responses in rice. Plant Phys. 168, 1476-U1697, doi: 10.1104/pp.15.00450

Change, B., and Maehly, A. C. (1955). Assay of catalase and peroxidase. Meth. Enzymol. 2, 764-775. doi: 10.1016/S0076-6879(55)02300-8
Barcode: 159078, dt: 21/07/2016) SRF fellowship to carryout the experiment smoothly.

\section{ACKNOWLEDGMENTS}

The authors are grateful to Rtd. Prof. Gundappagol, MS, NN for their continuous research support. The author sincerely thanks Karnataka-farmers who indeed helped to understand and analyze the real time problems while carrying out experimentation. This thesis will help the farmers not only to grow crops it helps them to reduce cost some extent.

Cheesman, J. M. (1988). Mechanisms of salinity tolerance in plants. J. Plant Phys. 87, 547-550. doi: 10.1104/pp.87.3.547

Dhingra, H. R., and Varghese, T. M. (1993). Flowering and male reproductive functions of chickpea (Cicer arietinum L.) genotypes as affected by salinity. Bio Plant 35:447-452. doi: 10.1007/BF02 928525

Dodd, I. C., and Alfocea, P. F. (2012). Microbial amelioration of crop salinity stress. J. Exp. Bot. 63, 3415-3428. doi: 10.1093/jxb/ers033

Dworkin, M., and Foster, J. W. (1958). Experiments with some microorganisms which utilize ethane and hydrogen. J. Bacter. 75, 592-603. doi: $10.1128 /$ jb.75.5.592-603.1958

Etesami, H., and Glick, B. R. (2020). Halotolerant plant growth-promoting bacteria: prospects for alleviating salinity stress in plants. Environ. Exp. Bot. 178:104124. doi: 10.1016/j.envexpbot.2020.104124

Etesami, H., and Maheshwari, D. K. (2018). Use of plant growth promoting rhizobacteria (PGPRs) with multiple plant 1187 growth promoting traits in stress agriculture: action mechanisms and future prospects. Ecotoxicol. Environ. Saf. 156, 225-246. doi: 10.1016/j.ecoenv.2018.03.013

Etesami, H., Mirsyed Hosseini, H., Alikhani, H. A., and Mohammadi, L. (2014). Bacterial biosynthesis of 1-aminocyclopropane-1-carboxylate (ACC) deaminase and indole-3-acetic acid (IAA) as endophytic preferential selection traits by rice plant seedlings. J. Plant. Growth Regul. 33, 654-670. doi: 10.1007/s00344-014-9415-3

Fageria, N. K., Gheyi, H. R., and Moreira, A. (2011). Nutrient bioavailability in salt affected soils. J. Plant Nutr. 34, 945-962. doi: 10.1080/01904167.2011.5 55578

FAO (2005). Salt-Affected Soils from Seawater Intrusion: Strategies for Rehabilitation and Management. Report of the Regional Workshop, Bangkok.

Flexas, J., Bota, J., Loreto, F., Cornic, G., and Sharkey, T. D. (2004). Diffusive and metabolic limitations to photosynthesis under drought and salinity in C3 plants. Plant Biol. 6, 269-279. doi: 10.1055/s-2004-8 20867

Flowers, T. J., and Colmer, T. D. (2015). Plant salt tolerance: adaptations in halophytes. Ann. Bot. 115, 327-331. doi: 10.1093/aob/mcu267

Flowers, T. J., Galal, H. K., and Bromham, L. (2010). Evolution of halophytes: multiple origins of salt tolerance in land plants. Funct. Plant Biol. 37, 604-612.

Gangwar, S., and Dubey, M. (2012). Effect on N and P uptake by chickpea (Cicer arietinum L.) as influenced by micronutrients and biofertilizers. Legume Research 35:164-168.

Giannopolities, C. N., and Ries, S. K. (1977). Superoxide dismutase. Part I: occurrence in higher plants. Plant Physiol. 59, 309-314. doi: 10.1104/pp.59.2.309

Guihua, S., Shuting, Z., Xiaojiao, L., Qipeng, J., and Wei, D. (2018). Soil acidification amendments change the rhizosphere bacterial community of tobacco in a bacterial wilt affected field. Appl. Microb. Biotechnol. 102, 9781-9791. doi: 10.1007/s00253-018-9347-0

Halverson, L. J., and Handelsman, J. (1991). Enhancement of soybean nodulation by Bacillus cereus UW85 in the field and in a growth chamber. Appl. Environ. Microb. 57, 2767-2770. doi: 10.1128/aem.57.9.2767-2770.1991

Han, H. S., and Lee, K. D. (2005). Plant growth promoting rhizobacteria effect on antioxidant status, photosynthesis, mineral uptake and growth of lettuce under soil salinity. Res. J. Agric. Biol. Sci. 1, 210-215. 
Honma, M., and Shimomura, T. (1978). Metabolism of 1aminocyclopropane-1-carboxylic acid. Agric. Biol. Chem. 42, 1825-1831. doi: 10.1080/00021369.1978.10863261

Jackson, M. L. (1973). Soil Chemical Analysis. New Delhi: Prentice Hall of India (Pvt.) Ltd.

Kang, S.-M., Khan, A. L., Waqas, M., You, Y.-H., Kim, J.-H., Kim, J.-G., et al. (2014). Plant growth-promoting rhizobacteria reduce adverse effects of salinity and osmotic stress by regulating phytohormones and antioxidants in Cucumis sativus. J. Plant Interact. 9, 673-682. doi: 10.1080/17429145.2014.894587

Klassen, S. P., and Bugbee, B. (2002). Sensitivity of wheat and rice to low levels of atmospheric ethylene. Crop Sci. 42, 746-753. doi: 10.2135/cropsci2002.7460

Klee, H. J., Hayford, M. B., Kretzmer, K. A., Barry, G. F., and Kishore, G. M. (1991). Control of ethylene synthesis by expression of bacterial enzyme in transgenic tomato plants. Plant Cell 3, 1187-1193. doi: 10.1105/tpc.3.11.1187

Mandal, A. K., Sharma, R. C., and Gurbachan, S. (2009). Assessment of salt-affected soils in India using GIS. Geoca Intell. 24, 437-456. doi: $10.1080 / 10106040902781002$

Mukherjee, A., Gaurav, A. K., Singh, S., Chouhan, G. K., Kumar, A., and Das, S. (2019). Role of potassium (K) solubilising microbes (KSM) in growth and induction of resistance against biotic and abiotic stress in plant: a book review. Clim. Change Environ. Sustain. 7, 212-214.

Mukherjee, S. P., and Choudhuri, M. A. (1983). Effect of some reducing agents on water stress-induced oxidative and deteriorative processes of Vigna seedlings. Biol. Plant 25:401. doi: 10.1007/BF02903135

Munns, R. (2002). Salinity, Growth and Phytohormones. Berlin: Springer.

Munns, R., and James, R. A. (2003). Screening methods for salinity tolerance: a case study with tetraploid wheat. Plant Soil 253, 201-218. doi: 10.1023/A:1024553303144

Munns, R., and Tester, M. (2008). Mechanisms of salinity tolerance. Ann. Rev. Plant Biol. 59, 651-681. doi: 10.1146/annurev.arplant.59.032607.092911

Nagaraju, Y., and Gundappagol, R. C., Mahadevaswamy (2020). Mining saline soils to manifest plant stress-alleviating halophilic bacteria. Curr. Microbiol. 77, 2265-2278. doi: 10.1007/s00284-020-02028-w

Neera, G., and Ranju, S. (2006). Changes in the nodular metabolism in desi and kabuli genotypes of chickpea (Cicer arietinum L.) under salt stress. Legume Res. 29, $1-10$.

Nishimura, T., Vertes, A. A., Shinoda, Y., Inui, M., and Yukawa, H. (2007). Anaerobic growth of Corynebacterium glutamicum using nitrate as a terminal electron acceptor. Appl. Microb. Biotech. 75, 889-897. doi: $10.1007 / \mathrm{s} 00253-007-0879-\mathrm{y}$

Patten, C. L., and Glick, B. R. (1996). Bacterial biosynthesis of indole-3-acetic acid. Can. J. Microb. 42, 207-220. doi: 10.1139/m96-032

Piper, C. S. (1966). Soil and Plant Analysis. Bombay: Hans Publishers, p. 368.

Podile, A. R. (1995). Seed bacterization with Bacillus subtilis AF1 enhances seedling emergence, growth and nodulation of pigeon pea. Indian J. Microb. $35,199-204$.

Qin, Y., Druzhinina, I. S., Pan, X., and Yuan, Z. (2016). Microbially mediated plant salt tolerance and microbiome based solutions for saline agriculture. Biotechnol. Adv. 34, 1245-1259.

Qurashi, A. W., and Sabri, A. N. (2013). Osmolyte accumulation in moderately halophilic bacteria improves salt tolerance of chickpea. Pak. J. Bot. 45, 1011-1016. Available online at: http://www.pakbs.org/.../40.pdf

Rao, D. L. N., Giller, K. E., Yeo, A. R., and Flowers, T. J. (2002). The effects of salinity and sodicity upon nodulation and nitrogen fixation in chickpea (Cicer arietinum). Ann. Bot. 89, 563-570. doi: 10.1093/aob/mcf097

Rogers, M. E., Craig, A. D., Munns, R., Colmer, T. D., and Nichols, P. G. H. (2005). The development of fodder plants for the salt-affected areas of southern and eastern Australia: an overview. Aust. J. Exp. Agric. 45, 301-329. doi: 10.1071/EA04020

Sathya, A., Vijayabharathi, R., and Gopalakrishnan, S. (2017). Plant growthpromoting actinobacteria: a new strategy for enhancing sustainable production and protection of grain legumes. Biotechnology 7:102. doi: 10.1007/s13205-017-0736-3

Seyoum, Z., and Diriba, S. (2017). Effects of salinity stress on chickpea (Cicer arietinum L.) landraces during early growth stage. Int. J. Sci. Rep. 3, 214-219. doi: 10.18203/issn.2454-2156.IntJSciRep20173093

Shirokova, Y., Forkutsa, I., and Sharafutdinova, N. (2000). Use of electrical conductivity instead of soluble salts for soil salinity monitoring in
Central Asia. Irrigat. Drain. Syst. 14, 199-205. doi: 10.1023/A:1026560 204665

Singh, B. K., Trivedi, P., Singh, S., Macdonald, C. A., and Verma, J. P. (2018). Emerging microbiome technologies for a sustainable increase in farm productivity and environmental security. Microbiol. Aust. 39, 17-23. doi: 10.1071/MA18006

Spaepen, S., Vanderleyden, J., and Remans, R. (2007). Indole-3-acetic acid in microbial and microorganism-plant signaling. FEMS Microbiol. Rev. 31, 425-448. doi: 10.1111/j.1574-6976.2007.00072.x

Strobel, B. W. (2001). Influence of vegetation on low-molecular-weight carboxylic acids in soil solution-a review. Geoderma 99, 169-198. doi: 10.1016/S0016-7061(00)00102-6

Subbiah, B. V., and Asija, G. L. (1956). A rapid procedure for the estimation of the available nitrogen in soil. Curr. Sci. 25, 259-260.

Subramaniam, G., Srinivas, V., Srinivasan, S., and Sameer, K. C. V. (2016). Plant growth-promotion and biofortification of chickpea and pigeon pea through inoculation of biocontrol potential bacteria, isolated from organic soils. SpringerPlus 5, 1-11. doi: 10.1186/s40064-016-3590-6

Takeno, S., Ohnishi, J., Komatsu, T., Masaki, T., Sen, K., and Ikeda, M. (2007). Growth and potential for amino acid production by nitrate respiration in Corynebacterium glutamicum. Appl. Microb. Biotech. 75:1173-1182. doi: 10.1007/s00253-007-0926-8

Tiwari, S., Lata, C., Chauhan, P. S., and Nautiyal, C. S. (2016). Pseudomonas putida attunes morphophysiological, biochemical, and molecular responses in Cicer arietinum L. during drought stress and recovery. Plant Physiol. Biochem. 99, 108-117. doi: 10.1016/j.plaphy.2015.11.001

Toro, M., Azcon, R., and Barea, J. M. (1997). Improvement of arbuscular mycorrhiza development by inoculation of soil with phosphatesolubilizing rhizobacteria to improve rock phosphate bioavailability $\left({ }^{32} \mathrm{P}\right)$ and nutrient cycling. Appl. Environ. Microb 63, 4408-4412. doi: 10.1128/aem.63.11.4408-4412.1997

Turner, N. C., Colmer, T. D., Quealy, J., Pushpavalli, R., Krishnamurthy, L., Kaur, J., et al. (2013). Salinity tolerance and ion accumulation in chickpea (Cicer arietinum L.) subjected to salt stress. Plant Soil 365, 347-361. doi: 10.1007/s11104-012-1387-0

Upadhyay, S. K., and Singh, D. P. (2014). Effect of salt-tolerant plant growthpromoting rhizobacteria on wheat plants and soil health in a saline environment. Plant Biol. 2014, 1-6. doi: 10.1111/plb.12173

Uroz, S., Calvaruso, C., Turpault, M. P., and FreyKlett, P. (2009). Mineral weathering by bacteria: ecology, actors and mechanisms. Trends Microb. 17, 378-387. doi: 10.1016/j.tim.2009.05.004

Yousef, S., Gholameraza, H., and Behrooz, E. (2008). Effect of salinity on growth and yield of desi and kabuli chickpea cultivars. Pak. J. Biol. Sci. 11, 664-667. doi: 10.3923/pjbs.2008.664.667

Zhao, H., Chen, K., Li, K., Du, W., He, S., and Liu, H. W. (2003). Reaction of $1-$ amino-2-methylene cyclopropane-1-carboxylate with 1- aminocyclopropane1-carboxylate deaminase: analysis and mechanistic implications. Biochemistry 42, 2089-2103. doi: 10.1021/bi020567n

Zhu, J. K. (2007). Plant Salt Stress. New York, NY: Wiley.

Conflict of Interest: The authors declare that the research was conducted in the absence of any commercial or financial relationships that could be construed as a potential conflict of interest.

Publisher's Note: All claims expressed in this article are solely those of the authors and do not necessarily represent those of their affiliated organizations, or those of the publisher, the editors and the reviewers. Any product that may be evaluated in this article, or claim that may be made by its manufacturer, is not guaranteed or endorsed by the publisher.

Copyright (c) 2021 Nagaraju, Mahadevaswamy, Naik, Gowdar, Narayanarao and Satyanarayanarao. This is an open-access article distributed under the terms of the Creative Commons Attribution License (CC BY). The use, distribution or reproduction in other forums is permitted, provided the original author(s) and the copyright owner(s) are credited and that the original publication in this journal is cited, in accordance with accepted academic practice. No use, distribution or reproduction is permitted which does not comply with these terms. 